\title{
Tracking pan-continental trends in environmental contamination using sentinel raptors-what types of samples should we use?
}

\author{
S. Espín ${ }^{1,2,}$ - A. J. García-Fernández ${ }^{1}$ D. Herzke ${ }^{3}$ R. F. Shore ${ }^{4}$ B. van Hattum ${ }^{5,16}$ • \\ E. Martínez-López ${ }^{1}$ - M. Coeurdassier ${ }^{6}$ - I. Eulaers ${ }^{7,14}$ - C. Fritsch $^{6}$. \\ P. Gómez-Ramírez ${ }^{1}$ V. L. B. Jaspers ${ }^{7,8}$ • O. Krone ${ }^{9}$ G. Duke ${ }^{10} \cdot$ B. Helander ${ }^{11}$ \\ R. Mateo ${ }^{12} \cdot$ P. Movalli ${ }^{13} \cdot$ C. Sonne ${ }^{14} \cdot$ N. W. van den Brink ${ }^{15}$
}

Accepted: 11 February 2016/Published online: 5 March 2016

(C) The Author(s) 2016. This article is published with open access at Springerlink.com

\begin{abstract}
Biomonitoring using birds of prey as sentinel species has been mooted as a way to evaluate the success of European Union directives that are designed to protect people and the environment across Europe from industrial contaminants and pesticides. No such pan-European evaluation currently exists. Coordination of such large scale monitoring would require harmonisation across multiple countries of the types of samples collected and analysedmatrices vary in the ease with which they can be collected
\end{abstract}

Electronic supplementary material The online version of this article (doi:10.1007/s10646-016-1636-8) contains supplementary material, which is available to authorized users.

\section{S. Espín}

sieslu@utu.fi; silvia.espin@um.es

1 Department of Toxicology, Faculty of Veterinary Medicine, University of Murcia, Campus de Espinardo, 30100 Murcia, Spain

2 Section of Ecology, Department of Biology, University of Turku, 20014 Turku, Finland

3 FRAM-High North Research Centre for Climate and the Environment, Norwegian Institute for Air Research, 9296 Troms $\varnothing$, Norway

4 NERC Centre for Ecology and Hydrology, Lancaster Environment Centre, Library Avenue, Bailrigg, Lancaster LA1 4AP, UK

5 Institute for Environmental Studies, VU University, De Boelelaan 1087, 1081 HV Amsterdam, The Netherlands

6 Chrono-Environnement, UMR 6249 University Bourgogne Franche-Comté/CNRS Usc INRA, 16 Route de Gray, 25030 Besançon Cedex, France

7 Behavioural Ecology and Ecophysiology Group, Department of Biology, University of Antwerp, Universiteitsplein 1, 2610 Wilrijk, Belgium and the information they provide. We report the first ever pan-European assessment of which raptor samples are collected across Europe and review their suitability for biomonitoring. Currently, some 182 monitoring programmes across 33 European countries collect a variety of raptor samples, and we discuss the relative merits of each for monitoring current priority and emerging compounds. Of the matrices collected, blood and liver are used most extensively for quantifying trends in recent and longerterm contaminant exposure, respectively. These matrices are potentially the most effective for pan-European biomonitoring but are not so widely and frequently

8 Department of Biology, Norwegian University of Science and Technology, EU2-169, Høgskoleringen 5,

7491 Trondheim, Norway

9 Leibniz Institute for Zoo and Wildlife Research, AlfredKowalke-Strasse 17, 10315 Berlin, Germany

10 Centre for the Environment, Oxford University Environmental Change Institute, South Parks Road, Oxford OX1 3QY, UK

11 Environmental Research \& Monitoring, Swedish Museum of Natural History, Box 50007, SE-104 05 Stockholm, Sweden

12 Instituto de Investigación en Recursos Cinegéticos-IREC (CSIC-UCLM-JCCM), Ronda de Toledo s/n, 13071 Ciudad Real, Spain

13 Department of Collections, Naturalis Biodiversity Center, Darwinweg 2, 2333 CR Leiden, The Netherlands

14 Department of Bioscience, Artic Research Centre (ARC), Århus University, Frederiksborgvej 399, PO Box 358, 4000 Roskilde, Denmark

15 Division of Toxicology, Wageningen University, PO Box 8000, NL-6700EA Wageningen, The Netherlands

16 Deltares, Marine and Coastal Systems, P.O. Box 177, 2600 MH Delft, The Netherlands 
collected as others. We found that failed eggs and feathers are the most widely collected samples. Because of this ubiquity, they may provide the best opportunities for widescale biomonitoring, although neither is suitable for all compounds. We advocate piloting pan-European monitoring of selected priority compounds using these matrices and developing read-across approaches to accommodate any effects that trophic pathway and species differences in accumulation may have on our ability to track environmental trends in contaminants.

Keywords Bird of prey - Contaminant - Monitoring · Sample type $\cdot$ Matrix

\section{Introduction}

Raptors (birds of prey and owls) were among the first wildlife species known to be affected by anthropogenic pollutants. Pesticide and/or contaminant related declines in peregrine falcon (Falco peregrinus), bald eagle (Haliaeetus leucocephalus), white-tailed sea eagle (Haliaeetus albicilla) and sparrowhawk (Accipiter nisus) populations have been widely documented in Europe and North America in the 20th Century (Hickey 1969; Ratcliffe 1980; Nisbet 1989; Newton and Wyllie 1992; Rutz et al. 2006; Sielicki and Mizera 2009). These were largely caused by primary and/or secondary exposure to organochlorine pesticides (OCPs), such as dichlorodiphenyltrichloroethanes (DDTs) and cyclodiene pesticides (Drins), other organochlorine pollutants such as polychlorinated biphenyls (PCBs), and toxic metals such as mercury $(\mathrm{Hg})$ and lead $(\mathrm{Pb})$ (Ratcliffe 1970; García-Fernández et al. 1995, 1996, 2005a, b; Weech et al. 2003; Mateo 2009). Organochlorine pesticides and pollutants (OCs) are now restricted in their use or banned in many countries but they are highly persistent in the environment and lower level exposure still occurs, particularly in higher trophic level wildlife (Sonne et al. 2010; Eulaers et al. 2011b; Luzardo et al. 2014). Other threats remain. For example, $\mathrm{Pb}$ intoxication in birds of prey, caused by ingestion of $\mathrm{Pb}$ shot and ammunition fragments in unretrieved game, is an ongoing concern for raptor populations (Krone et al. 2004, 2006, 2009; García-Fernández et al. 2005a; Hunt et al. 2006; Helander et al. 2009; Finkelstein et al. 2012; Group of Scientists 2014). There is also exposure to newer compounds, such as new brominated and organophosphate flame retardants and pharmaceuticals (Cuthbert et al. 2011; Covaci et al. 2011). Many of these substances are associated with adverse health effects on the endocrine, immune, nervous and reproductive systems in both humans (Lutz et al. 1999; Yorifuji et al. 2008; Hatcher-Martin et al. 2012) and wildlife (Mateo et al. 2003; Cortinovis et al. 2008; Henny et al., 2009;
Naidoo et al. 2009; Frederick and Jayasena 2010; Harris and Elliott 2011). In some cases, they can cause widespread acute mortality and endanger the survival of species; examples include the effects of diclofenac on Gyps vultures in Asia (Oaks et al. 2004) and $\mathrm{Pb}$ in the California condor (Gymnogyps californianus; Finkelstein et al. 2012).

The vulnerability of raptors to environmental contaminants is in part due to their trophic position at the top of foodpyramids. Persistent, bioaccumulative contaminants can be transferred, and in some cases biomagnified, along food chains and accumulated in high concentrations by apex predators (Furness 1993; Elliott et al. 2009; Guigueno et al. 2012). In addition, raptors are vulnerable to (primary or secondary) poisoning because of facultative scavenging and of an increased likelihood that sick and moribund prey are likely to be caught (Langlier 1993; Green et al. 2004), as has been demonstrated for strychnine (Martínez-López et al. 2006) and is likely to occur for currently-used compounds such as anticoagulant rodenticides and anticholinesterase compounds (e.g. Rattner et al. 2014a). Early observations on the impacts of OCs on raptors spawned an increase in the numbers of analytical studies using raptor tissues and eggs and subsequent recognition that raptors can be powerful sentinels of marine and terrestrial environmental contamination (Sergio et al. 2005; Rattner 2009). As a result, raptors have been widely used in some regions of the world in biomonitoring programs. Such programmes assess spatial and temporal trends in concentrations of bioaccumulative environmental chemicals and investigate associated effects on populations (GómezRamírez et al. 2014). They can provide early warning of the potential impacts in humans (Pain et al. 2010), protected wildlife species and on the wider environment and they can be used to track the success of mitigation in reducing exposure (Helander 2003; Shore et al. 2005; García-Fernández et al. 2005b).

In the European Union (EU), regulation of industrial chemicals, plant protection products, pharmaceuticals, and biocides is governed by directives such as Regulation (EC) No 1907/2006 and ammendements (REACH-Registration, Evaluation, Authorisation \& Restriction of Chemicals), Regulation (EC) No 1107/2009 concerning the authorisation of plant protection products, Regulation (EC) No 726/2004 concerning the authorisation of human and verterinary pharmaceuticals, and The Biocidal Product Regulation (BPR, Regulation (EU) 528/2012). These directives apply across all EU Member States but lack any monitoring of their effectiveness in protecting against environmental pollution. This may be partly because such monitoring is challenging given the large spatial scales involved. However, a recent survey (Gómez-Ramírez et al. 2014) identified a number of European long-term, national scale, biomonitoring programmes that use raptors as 
sentinels of environmental contamination. Although almost all the programmes are restricted to western European countries, the types of biological samples needed for analysis are routinely collected throughout all of Europe, typically as part of surveys of raptor populations (Derlink et al. in preparation). Incorporation of such samples into existing contaminant monitoring programmes could extend the reach of pollution monitoring to a pan-European scale and thereby provide assessment of the effectiveness of regulation of chemicals across the EU.

Coordination and integration of large spatial scale monitoring across multiple independent monitoring programmes is challenging. It requires mutual sharing, dissemination and adoption of best practice in terms of the types of samples collected and analysed (Gómez-Ramírez et al. 2014). Sample matrices vary in the information they provide about exposure and effects and not all are suitable for biomonitoring. The scientific relevance of each sample type for monitoring depends on the objectives of the study, for example if the monitoring program is intended to detect contaminant trends or evaluate effects, and if so at what level of biological organization. Furthermore, choice of matrix should ideally be related to the toxicokinetics and toxicodynamics of the compounds of interest and the site of toxic action (Walker et al. 2008). It is also important to use matrices in which pollutant concentrations are above the analytical limit of detection in a significant proportion of the samples and, more pragmatically, to use those types of samples that are likely to be widely available. However, we are unaware of any published evaluation that examines the potential widescale availability of different types of sample for analysis or that evaluates their usefulness and limitations for monitoring contaminants. This lack of information presents a significant barrier to developing EU-scale monitoring for contaminants using raptor tissues.

Our aim in the present study was to undertake the first ever assessment of the potential widescale availability of raptor samples in Europe for biomonitoring and the relative merits of each. We combined data from a recent European inventory on contaminant monitoring in raptors (GómezRamírez et al. 2014) with a survey of raptor population monitoring activities that are ongoing over the same geographical area (Derlink et al. in preparation). This allowed us to ascertain which sample matrices might be most available for monitoring and which contaminants are currently prioritized for monitoring in birds of prey and owls in Europe. These earlier surveys did not provide information on which sample types are predominantly used to analyse different contaminants. We therefore additionally reviewed 249 papers published between 1966 and 2015, which reported contaminant concentrations in raptors in Europe. This provided information on sample types most widely used to monitor each of our identified priority contaminant classes. Details of the methods by which we searched the literature are given in Supporting Information S.I. Document 1. Our specific objectives were to: (i) determine which raptor samples are currently collected across Europe; (ii) assess which sample types are predominantly used to measure priority compound groups, and (iii) review the suitability of these different sample types for contaminant monitoring in general and for priority compounds specifically.

\section{Collection of different sample types across Europe}

Most raptors are protected species and lethal sampling of individuals is not permissible on legal or ethical grounds. Active monitoring of raptors is limited to (invasive and noninvasive) non-destructive sampling. This includes blood and biopsies taken from live birds, plucked feathers and preen oil, and samples taken without contact with a living bird such as moulted feathers, addled or deserted eggs, regurgitated pellets, excrement, and tissues from carcasses that have been found and collected. Collection of samples can be demanding logistically since nests are often difficult to access and collection usually requires skilled and trained personnel, specialised equipment and legal permits. Therefore, if monitoring is to be conducted across continental and other large spatial scales, it is only likely to be feasible if it utilises samples that are already being collected as part of existing monitoring programmes or after careful prior selection of the suitable sample material and species. Two recent inventories collected by questionnaires (Gómez-Ramírez et al. 2014; Derlink et al. in preparation) provide, for the first time, information on the extent of raptor monitoring and sample collection throughout Europe. We combined the data from these two surveys and found that, within Europe, there was information for 281 different raptor monitoring schemes from across 35 European countries (Table 1; S.I. Fig. 1). Of these, 182 programmes from 33 countries collect raptor samples. The United Kingdom (UK), Sweden and Italy are the countries with the highest number of schemes collecting samples, while there appeared to be no sample collections of raptor material in Luxembourg and Serbia (Table 1). There were no responses to the questionnaires from Greece, Lithuania, Albania, Moldova, Macedonia and Montenegro and so we are unaware of any raptor monitoring schemes in those countries.

Of the different sample types, feathers and addled/deserted eggs are the most frequently collected matrices across the 182 schemes (55 and $50 \%$ of schemes, respectively; Table 1 ). Food remains (45\%), regurgitated pellets $(36 \%)$, internal tissues $(34 \%)$, and blood $(30 \%)$ were also commonly collected. The questionnaires indicated that carcasses were collected by 78 schemes and presumably crop and gizzard contents and internal organs 
Table 1 Number of schemes that collect each type of sample in raptors from European countries

\begin{tabular}{|c|c|c|c|c|c|c|c|c|c|}
\hline & \multirow{2}{*}{$\begin{array}{l}\text { Number } \\
\text { Schemes }\end{array}$} & \multicolumn{8}{|c|}{ Samples collected } \\
\hline & & Feather & Egg & Food remains & Carcass & Internal tissues & Blood & Pellets & Preen oil \\
\hline Austria & 5 & 3 & 2 & 4 & 2 & & 1 & 2 & \\
\hline Belarus & 1 & 1 & 1 & 1 & & & 1 & 1 & \\
\hline Belgium & 5 & 2 & 1 & 1 & 2 & 1 & 1 & 1 & 1 \\
\hline Bosnia/herzegovina & 3 & & & & & & & 1 & \\
\hline Bulgaria & 1 & 1 & 1 & 1 & & 1 & 1 & 1 & \\
\hline Croatia & 4 & & & 2 & & & & & \\
\hline Cyprus & 2 & & 1 & 1 & 1 & & & 1 & \\
\hline Czech Republic & 1 & & 1 & 1 & & & 1 & & \\
\hline Denmark and Greenland & 6 & 2 & 2 & 1 & & 1 & 2 & & 1 \\
\hline Estonia & 7 & 3 & 1 & 2 & 1 & & 2 & 2 & \\
\hline Finland & 8 & 4 & 4 & 2 & 3 & 3 & & 1 & \\
\hline France & 11 & 2 & 4 & & 5 & 5 & 2 & & 1 \\
\hline Georgia & 2 & 1 & & & 1 & & & & \\
\hline Germany & 7 & 1 & 6 & & 1 & 3 & 2 & & \\
\hline Hungary & 10 & 4 & 3 & 7 & 3 & 1 & 1 & 6 & \\
\hline Iceland & 1 & 1 & 1 & 1 & 1 & 1 & 1 & 1 & \\
\hline Ireland & 10 & 8 & 3 & 7 & 9 & 4 & 4 & 6 & \\
\hline Italy & 29 & 11 & 5 & 5 & 9 & 10 & 6 & 4 & \\
\hline Latvia & 4 & 2 & 2 & 3 & 1 & & 1 & 1 & \\
\hline Luxembourg & 2 & & & & & & & & \\
\hline Netherlands & 4 & 1 & 1 & & & & 1 & & 1 \\
\hline Norway & 5 & 5 & 2 & & 2 & 1 & 3 & & 2 \\
\hline Poland & 1 & & & & & & 1 & & \\
\hline Portugal & 14 & 7 & 3 & 5 & 4 & 2 & 4 & 7 & \\
\hline Romania & 3 & 1 & & 2 & & & 1 & 2 & \\
\hline Russian Federation & 2 & 1 & 1 & 2 & 1 & 1 & 1 & 2 & \\
\hline Serbia & 1 & & & & & & & & \\
\hline Slovakia & 10 & 3 & 4 & 5 & 4 & 3 & 1 & 3 & \\
\hline Slovenia & 11 & 2 & 1 & 2 & 3 & 1 & 1 & 3 & \\
\hline Spain & 9 & 7 & 5 & & 5 & 5 & 8 & 4 & \\
\hline Sweden & 30 & 11 & 9 & 4 & 2 & 7 & 2 & 2 & \\
\hline Switzerland & 5 & 2 & 1 & & 1 & 1 & 1 & & \\
\hline Turkey & 7 & 3 & 1 & 1 & 1 & 1 & 1 & 2 & \\
\hline Ukraine & 2 & 1 & & & & & & 1 & \\
\hline United Kingdom & 58 & 10 & 25 & 21 & 16 & 10 & 3 & 12 & \\
\hline Total schemes & 281 & 100 & 91 & 81 & 78 & 62 & 54 & 66 & 6 \\
\hline Total countries & 35 & 28 & 27 & 23 & 23 & 20 & 27 & 23 & 5 \\
\hline
\end{tabular}

are likely to be available from those carcasses that are not severely decomposed; the questionnaire returns on the number of schemes collecting food remains and internal tissues may therefore be an underestimate. Preen oil was collected by only a few (3\%) schemes, perhaps reflecting the fact that is only relatively recently that is has been used for monitoring contaminants in raptors (van Den Brink 1997; Yamashita et al. 2007; Jaspers et al. 2008, 2011; Eulaers et al. 2011b).

\section{What contaminants are measured in different sample matrices?}

The scope of current contaminant monitoring programmes using raptors (Gómez-Ramírez et al. 2014) suggests that, in Europe, the priority compounds of interest remain persistent organic pollutants (POPs). These include organochlorine insecticides (measured in 42 schemes from 12 countries), polychlorinated biphenyls (41 schemes from 13 countries) 
and brominated flame retardants (21 schemes from 10 countries). Perfluorinated compounds which include perfluorooctanesulfonic acid (PFOS), more recently classed as a POP in the Stockholm Convention, are monitored in fewer (7) schemes (from 5 countries); as are dioxins and furans (4 schemes from 3 countries). Two other compound classes, metals/metalloids and anticoagulant rodenticides, are also widely monitored in raptors across Europe ( 37 schemes from 13 countries and 14 schemes from 6 countries, respectively; Gómez-Ramírez et al. 2014). Although other various compounds are measured as part of investigations into accidental and deliberate poisoning of raptors in Europe, they are not the focus of the present study (see reviews by Berny 2007; Guitart et al. 2010).

Many of the types of raptor sample that are widely collected throughout Europe (Table 1) can be used to monitor these priority contaminants (Gómez-Ramírez et al. 2014). Chemical analysis provides a quantitative measure of exposure/accumulation while genetic and stable isotope analysis of some matrices (feathers, blood and internal tissues) can sometimes be used to identify sources of exposure (Scheuhammer and Templeton 1998; Podlesak et al. 2005; Elliott et al. 2009; Hobson 2011). Other matrices (blood, internal tissues, faeces) are also useful for measuring effect biomarkers (Martinez-Haro et al. 2011b; Bourgeon et al. 2012; Espín et al. 2015). Our review of 249 papers indicated that eggs and liver are the preferred sample matrices when analysing contaminants and were used in twice as many studies as other matrices (Table 2). Studies that used eggs predominantly focussed on POPs (93\% of 88 studies reporting egg contaminant concentrations) whereas liver was used for analysing all the priority compound groups. Most other internal tissue matrices were analysed for a large variety of compound classes, except for fat (used for POPs and perfluorinated compounds only) and bone (predominantly used when quantifying $\mathrm{Pb}$ ). Of samples that can be taken from live birds, feathers were used in 6-10 fold more studies that preen oil or regurgitated pellets and were analysed for all priority compound groups other than anticoagulant rodenticides.

Given the potentially wide but variable availability of raptor samples across Europe, it can be difficult to determine which sample matrices may be the best for widescale monitoring of priority compounds. We therefore critically evaluate the factors that affect the usefulness of each matrix for contaminant monitoring in general and for specific priority compound groups in particular. Consideration of sampling, transport and storage of these matrices is also important when selecting matrices for analysis and these are briefly summarised in S.I. Table 1 but are otherwise outside the scope of this paper; they are covered in more detail by Espín et al. (2014a).

\section{The relative merits of different sample matrices for contaminant monitoring}

\section{Addled and deserted eggs}

For both ethical and legal reasons, the taking of unhatched viable eggs is permitted only in exceptional circumstances

Table 2 Number of published studies (identified from a literature review—see text for details) that analysed different pollutant groups in various sample types from raptor and owl species from Europe

\begin{tabular}{|c|c|c|c|c|c|c|c|}
\hline & \multirow{2}{*}{$\begin{array}{l}\text { No/studies in which } \\
\text { sample type analysed }\end{array}$} & \multicolumn{6}{|c|}{ No/studies measuring contaminant in each matrix type } \\
\hline & & $\begin{array}{l}\text { POPs } \\
n=137\end{array}$ & $\begin{array}{l}\text { PFASs } \\
n=11\end{array}$ & $\begin{array}{l}\text { Lead } \\
n=71\end{array}$ & $\begin{array}{l}\text { Mercury } \\
n=59\end{array}$ & $\begin{array}{l}\text { Cadmium } \\
n=48\end{array}$ & $\begin{array}{l}\text { Anticoagulan } \\
\text { rodenticides } \\
n=20\end{array}$ \\
\hline Eggs & 88 & 82 & 4 & 11 & 13 & 10 & 0 \\
\hline Feathers & 45 & 10 & 4 & 15 & 21 & 11 & 0 \\
\hline Blood/plasma/serum & 42 & 17 & 3 & 21 & 5 & 15 & 1 \\
\hline Liver & 98 & 40 & 3 & 33 & 24 & 23 & 18 \\
\hline Kidney & 40 & 11 & 0 & 21 & 19 & 17 & 0 \\
\hline Muscle & 22 & 15 & 1 & 3 & 3 & 3 & 0 \\
\hline Bone & 18 & 0 & 0 & 17 & 0 & 8 & 0 \\
\hline Brain & 15 & 7 & 0 & 5 & 2 & 4 & 0 \\
\hline Fat & 13 & 12 & 1 & 0 & 0 & 0 & 0 \\
\hline Preen oil & 7 & 5 & 2 & 0 & 0 & 0 & 0 \\
\hline Regugitated pellets & 4 & 0 & 0 & 3 & 0 & 0 & 1 \\
\hline
\end{tabular}

$n$ number of studies reporting concentrations of that compound group

Total number of studies reviewed was 249 , see S.I. Table 3 for references. Studies often analysed more than one sample type and multiple contaminant groups 
and requires specific licensing from national regulatory bodies; it is not considered further in the present paper. In contrast, licensed collection and storage of addled and deserted eggs is relatively easy, as reflected by their widespread collection amongst groups that monitor European raptors (91 schemes from 27 countries-Table 1, S.I. Fig. 1). They are important for and widely used in contaminant monitoring studies (Table 2) in part because many pollutants, particularly organic contaminants, are sequestered in eggs (or sometimes eggshells) during formation of the egg. Development of the chick embryo depends on a first phase that consists of the synthesis of lipids by the maternal liver and transport of these lipids to the ovary for incorporation into the maturing oocyte prior to the laying of the egg (Speake et al. 1998). During this process, maternal lipophilic contaminants may be transported along with lipid reserves into the developing oocyte. Thus, contaminant burdens in eggs are directly related to levels in the adult breeding female (Becker and Sperveslage 1989), and reflect exposure in this precise segment of the population that has similar hormonal status and is generally in a healthy condition (Dell'Omo et al. 2008). This is useful for biomonitoring as it may help reduce intraspecific variability in accumulation, although the derived data is not directly indicative of exposure in males and nonbreeders.

The necessary restriction of being able to use only failed/addled or deserted eggs limits the number of samples available for analysis. There are also other disadvantages for biomonitoring. Addled eggs, by definition, are a nonrandom sample in that they only represent failed breeding outcomes. They therefore have a greater likelihood of containing contaminant concentrations that cause adverse effects on hatchability (Henny and Elliott 2007), although failed eggs can sometimes contained higher concentrations than addled eggs (Jaspers et al. 2005). Furthermore, egg sequence is often unknown but can affect pollutant concentrations (Furness and Camphuysen 1997) as can microbial decomposition, the extent of which will depend on the time elapsed between embryo death and collection of the egg (Mulhern and Reichel 1971; Herzke et al. 2002). Biases associated with decomposition are likely to be less significant for highly persistent compound groups but any detection of less persistent transformation products, such as heptachlor exo-epoxide and oxychlordane, may be the result of microbiological degradation in the egg and not reflect either maternal exposure or that of successfully hatched young chicks (Herzke et al. 2002).

While egg contaminant concentrations provide information on exposure in breeding females, the breeding strategy of the species can influence whether egg concentrations reflect current local exposure or exposure in other areas used by females before nesting (Nisbet and Reynolds
1984; Henny and Blus 1986). Income breeders fuel reproductive expenditure from food ingested immediately before and during egg production whereas capital breeders utilise stored energy to a much greater extent (Bonnet et al. 1998). Capital breeding females may thus accumulate lipophilic contaminants in lipid laid down while on wintering areas and migration and subsequently transfer those contaminants into eggs on the breeding area. However, raptors are often classified as income breeders as they are largely thought to rely on food intake rather than reserves to service the energetic costs of breeding (Durant et al. 2000), and so egg concentrations in raptor eggs most likely reflect exposure within breeding territories.

Eggs are particularly useful in ecotoxicological studies as contaminant concentrations indicate the load that the nestling is exposed to during embryonic development (García-Fernández et al. 2008). Analysis of egg contents has been widely used to relate exposure to likely or observed reproductive effects (Helander et al. 2002; Lindberg et al. 2004; Herzke et al. 2005; Martinez-Lopez et al. 2007; Vetter et al. 2008; Henny et al., 2009; Pereira et al. 2009; Best et al. 2010; Harris and Elliott 2011; Crosse et al. 2012) and egg concentrations associated with adverse effects on hatching and chick development have been suggested for various contaminants (Blus 2011; Elliott and Bishop 2011; Harris and Elliott 2011; Shore et al. 2011). In addition, eggshell morphometrics can be used to detect shell thinning, an early warning biomarker that occurs at exposures far below those that cause direct impacts on reproduction (Lundholm 1997; Helander et al. 2002); methods to calculate egg weight, length and width, and eggshell weight are described by Espín et al. (2014a) and the relative merits of different ways of calculating shell thickness have been extensively explored (S.I. Document 2). However, it has been argued that, while monitoring of addled eggs may be adequate for evaluating spatial and temporal patterns in contamination, random collection of fresh eggs is needed to best evaluate how reproductive success in the clutch is related to contaminant concentrations (Henny and Elliott, 2007). Such egg collections may be possible for common species which lay two or more eggs, if done over limited spatial scales and at intervals of two or more years and without causing any significant conservation effect. The resultant analysis can provide key information on the ecological importance of the contamination patterns that are revealed through widespread biomonitoring of addled eggs.

Typically, whole egg contents are used for contaminant analysis since it is not possible to separate yolk and albumin in addled eggs. The contents of such eggs can range from undifferentiated material to fully developed embryonic tissue (Espín et al. 2014a). Embryo development can deplete the lipid content of the egg contents and elevate 
associated concentrations of contaminants expressed on a lipid weight basis (Newton and Bogan 1978; Peakall and Gilman 1979; Helander et al. 1982) and contaminant concentrations in eggs with different stages of embryo development may need to be reported separately. Eggs also lose weight post-laying through diffusive loss of water vapour (Hoyt 1979) and failed eggs can desiccate to varying degrees, although this loss can be estimated from the dimensions of the egg and a species-specific or generalised weight coefficient (Stickel et al. 1973; Best et al., 2010) (S.I. Document 3). Metal and organic contaminant concentrations in eggs are typically expressed on a dry weight and wet or lipid weight basis, respectively and so may need to be corrected and/or normalized for lipid and water content (Espín et al. 2014a); both factors ideally should be reported alongside any concentration data.

In terms of the value of eggs for monitoring particular contaminant groups, we are unaware of any studies that have determined anticoagulant rodenticide residues in raptor eggs (Table 2) although maternal transfer to eggs has been reported in chickens dosed with brodifacoum (Fisher 2009). In contrast, POPs are frequently measured in failed raptor eggs; $60 \%$ of the 137 studies on POPs that we reviewed reported concentrations in eggs (Table 2). These studies largely focussed on legacy POPs but eggs can be used to monitor newer POPs such as poly- and perfluoroalkyl substances (PFASs). A 35-year study of sea eagles detected relatively high levels of PFAS in eggs (Faxneld et al. 2014) and, of the 11 studies reporting PFAS concentrations in raptors that we reviewed (Table 2), a third used eggs. Addled and deserted eggs are also used as indicators of exposure to toxic metals, particularly $\mathrm{Hg}$ (Negro et al. 1993; Pain et al. 1999; Nygård 1999; Blanco et al. 2003). Laying females excrete approximately $20 \%$ of their soft tissue methyl $\mathrm{Hg}(\mathrm{MeHg})$ into eggs (Lewis et al. 1993) and, because $\mathrm{Hg}$ occurs mainly as $\mathrm{MeHg}$ in eggs (Ackerman et al. 2013), total Hg can be used as a surrogate measurement for $\mathrm{MeHg}$. $\mathrm{Hg}$ is not thought to cause significant eggshell thinning (Spann et al. 1972; Heinz 1974; Hill and Shaffner 1976) but MeHg is teratogenic in birds, increasing the incidence of malformations and embryonic mortality (Borg et al. 1969; Hoffman and Moore 1979; Heinz and Hoffman 2003; Frederick and Jayasena 2010). In contrast to $\mathrm{Hg}$, little $\mathrm{Pb}$ is transferred from the female to eggs (Scheuhammer 1987; Furness 1993), although $\mathrm{Pb}$ may occur in eggshells as it acts as a calcium analogue (Pounds 1984; Lundholm and Mathson 1986; Scheuhammer 1987; Dauwe et al. 1999). Very little Cd is transferred to eggs of birds and often concentrations are below detection limits, regardless of the dietary levels of $\mathrm{Cd}$ consumed (Scheuhammer 1987; Furness 1996). Given this, it is perhaps surprising that a similar proportion of the egg contaminant studies we reviewed reported $\mathrm{Pb}$ and $\mathrm{Cd}$ as well as Hg (14-22 \%; Table 2). This may perhaps simply reflect the potential for simultaneous determination of all three elements using inductively-coupled plasma mass spectrometry techniques, although this sometimes may be at a cost of reduced sensitivity for some elements.

\section{Feathers}

Feathers are the sample type that are collected across more schemes and countries than any other sample type (Table 1) and so are potentially an important resource for contaminant monitoring. However, only 45 of the 249 raptor studies we reviewed (18\%) used feathers (Table 2). General attributes that make feathers useful for monitoring contaminants are: (i) they can be plucked in small numbers without causing permanent damage and so are minimally invasive; (ii) it is possible to pluck repeated samples from the same individual to assess changes over time; (iii) samples can also be collected from carcasses or as moulted feathers regardless of season, age or gender of the bird; (iv) samples are not readily degraded and can be transported and stored at room temperature; (v) samples are often available as historic samples from museum specimens, thereby providing opportunities to measure historic temporal trends in exposure. In addition, feathers can be used to measure biomarkers related to stress, such as fluctuating asymmetry and corticosterone levels (Bustnes et al. 2002; Bortolotti et al. 2008; Sillanpää et al. 2010; Strong et al. 2015).

All types of feathers can be used for contaminant analysis and as a tool for other studies, such as genetic studies (Speller et al. 2011; Presti et al. 2013). Choice of feather type can depend on the moulting pattern of the species, preening behaviour and the end point of the study. We reviewed 45 studies that analysed raptor feathers (Table 2) and $47 \%$ used flight feathers, $44 \%$ body feathers and $38 \%$ tail feathers; more than one feather type was used in some studies. Both plucked and moulted feathers were analysed. When feathers have to be plucked (or cut close to the skin) from live birds, body feathers rather than flight feathers are normally used so as to avoid impairment of flight (Espín et al. 2014a); plucking or cutting feathers may also require a permit. Overall, we found that feathers plucked from live birds were used in about half as many studies as feathers plucked from dead birds found in the field or from museum collections (24 vs $56 \%$ of the 45 studies we reviewed). Moulted feathers are easier to collect in the field than plucked feathers, but have the disadvantage that information on age, sex and body condition of the bird from which the feather has been shed, and the time of moult, is usually lacking; all can affect feather pollutant concentrations (García-Fernández et al. 2013a). Overall, use of moulted feathers ( $29 \%$ of the 45 studies reviewed) appears to be similar to that of plucked 
feathers from live birds; in some studies moulted and plucked feathers have both been analysed. In some circumstances, analysis of moulted feathers may be the only way to monitor pollutant exposure, and feathers that fall into or just below the nest and look new are most probably from nesting parent birds.

Contaminants are deposited in feathers only while they are growing and there is no ongoing homeostasis between blood and feather concentrations, unlike between blood and internal tissues (Burger 1993; García-Fernández et al. 2013a). Despite this, several authors have found significant correlations between pollutant concentrations in feathers and in blood or internal tissues (Thompson et al. 1991; Dauwe et al. 2002; Jaspers et al. 2007a, 2011, 2013a; Eulaers et al. 2011a; Rajaei et al. 2011; Espín et al. 2014c). Moreover, some papers have described significant correlations between lead and cadmium concentrations in the feathers of adults and in the blood of their nestlings (Martínez-López et al. 2004, 2005). However, such associations are not always manifest (Dauwe et al. 2005; Jaspers et al. 2006, 2007b; Eagles-Smith et al. 2008; Espín et al. 2010a, 2012b), largely for two reasons. First, there may be significant temporal displacement between feather growth (and associated deposition of pollutant in the feather) and collection of internal tissues, during which time post feather-growth changes in diet and/or fat mobilization may alter internal tissue contaminant concentrations (García-Fernández et al. 2013a; Eulaers et al. 2014b). Second, there may be external contamination on the surface of the feather (Dauwe et al. 2003; Jaspers et al. 2008; Espín et al. 2010b; Cardiel et al. 2011), which in turn is affected by preening behaviour and by moult strategy. Moult is completed within one year in smaller species but can extend over two or more years in larger species (Hardey et al. 2006) and protracted moult can enhance inter-feather variability in age and the associated period over which external contamination can occur.

Analysis of recently grown feathers (such as those plucked from nestlings) or continuously replaced feathers reduces the issues both of temporal displacement and, to a large extent, external contamination (Jaspers et al. 2004). Where older feathers have to be used, variability due to external contamination can be reduced by restricting analysis to the shaft or rachis as external contamination tends to be greater for the vane than the shaft and the shaft is more easily and effectively cleaned (Jaspers et al. 2007a; Cardiel et al. 2011; Espín et al. 2012a; García-Fernández et al. 2013a). Overall though, many studies have primarily addressed the issue of external contamination of feathers by washing. This indeed may be the only viable option for museum feathers which may have been treated with arsenic, mercuric or insecticides compounds (Espín et al. 2014a; Sánchez-Virosta et al. 2015) or with organic preservatives that can change metals levels in feathers (Hogstad et al. 2003). In general, feathers are washed prior to analysis for metals with various combinations of deionised water, acetone, Triton X-100 and nitric acid (Burger and Gochfeld 2001; Dauwe et al. 2003; Jaspers et al. 2004; Cardiel et al. 2011; Espín et al. 2012a, 2014c) while distilled water tends to be used when analysing POPs (Jaspers et al. 2007a, b; Behrooz et al. 2009; Eulaers et al. 2011a, b, 2013, 2014a, b; Espín et al. 2012b). However, it has been argued that washing techniques tested to date are not effective in removing all external contamination (Jaspers et al. 2004, 2008, 2011) and further studies are needed to determine reliable methods for discriminating between internal and external contamination (Cardiel et al. 2011).

Concentrations of pollutants in feathers are typically expressed in ng/g feather. Bortolotti (2010) demonstrated that variation in mass and growth rate between feathers may affect the interpretation of contaminant concentrations. Therefore, feather concentrations should preferably be expressed as a function of deposition rate (García-Fernández et al. 2013a) in addition to a mass-based unit. The former is only possible when growth bars are visible in the feather (one pair of growth bars, dark and light, represents a 24-h period of growth), or when the growth rate of the feather is known (García-Fernández et al. 2013a); further studies are needed to determine the growth rate of feathers in some raptor species.

Feathers have been used to measure concentrations of all the major compounds that are monitored in raptors in Europe, except anticoagulant rodenticides (Table 2). They were originally mainly used for monitoring metals including $\mathrm{Cd}$ and $\mathrm{Pb}$ (Denneman and Douben 1993; Martínez-López et al. 2002, 2005; Dauwe et al. 2003), although there remains uncertainty over the suitability of feathers for monitoring environmental $\mathrm{Cd}$ concentrations. Some authors report that external contamination of feathers with $\mathrm{Cd}$ is minimal (Burger 1993; Ek et al. 2004) but others conclude that external contamination cannot be neglected (Pilastro et al. 1993; Dauwe et al. 2003; Jaspers et al. 2004). Cd concentrations in feathers have been correlated with those in internal tissues in some studies (Pilastro et al. 1993; Agusa et al. 2005) but not others (Nam et al. 2005; Orlowski et al. 2007). External contamination of feathers with $\mathrm{Pb}$ is known to be problematic. While feather $\mathrm{Pb}$ concentrations have been shown to be correlated with concentrations in internal tissues in juvenile birds (Golden et al. 2003), external $\mathrm{Pb}$ contamination after feather formation can elevate total feather $\mathrm{Pb}$ concentrations and is difficult to remove (Dauwe et al. 2002, 2003; Pain et al. 2005; Cardiel et al. 2011). Adult feathers subject to atmospheric $\mathrm{Pb}$ deposition for long periods may be strongly affected by external contamination (Franson and Pain 2011).

Mercury has also been extensively monitored in feathers (Lindberg and Odsjö 1983; Ortego et al. 2006; Espín et al. 
2014c) and, like $\mathrm{Pb}$ and $\mathrm{Cd}$, it is transferred from blood into feathers. MeHg binds with keratin uniformly along the feather (Thompson and Furness 1989a, b; Hahn et al. 1993; Dauwe et al. 2003; Misztal-Szkudlińska et al. 2012) and concentrations reflect those in blood during the period of feather growth (Lewis and Furness 1991). Unlike Pb, moult is a significant elimination pathway of $\mathrm{Hg}$. Tissue $\mathrm{Hg}$ concentrations decline during moult and 70-93\% of the total $\mathrm{Hg}$ body burden can be sequestered in plumage (Burger et al. 1993). External contamination is typically small relative to total feather $\mathrm{Hg}$ burden, causing little spurious inter-feather variation (Lindberg and Odsjö 1983; Dauwe et al. 2003; Jaspers et al. 2004), and feather Hg concentrations tend to be correlated with residues in internal tissues (Thompson et al. 1991). Body contour feathers may be most representative of total body $\mathrm{Hg}$ burden as inter-feather variation is lower than in primaries (Furness et al. 1986). However, it has been suggested that feathers from nestlings are the best indicators of local $\mathrm{Hg}$ pollution (Solonen et al. 1999). $\mathrm{Hg}$ in the first down of chicks is derived from $\mathrm{Hg}$ in the egg while levels in developing non-down feathers reflect $\mathrm{Hg}$ concentrations in food given to the chick. $\mathrm{Hg}$ in both feather types therefore reflects $\mathrm{Hg}$ pollution in the diet of the provisioning adult birds. In addition, critical feather $\mathrm{Hg}$ concentrations that are associated with reproductive impairment (lower clutch and egg size, reduced hatching rate and decreased chick survival) have been suggested (NAS 1978).

More recently, there has been a focus on measuring legacy and emerging POPs in feathers (Jaspers et al. 2006, 2007b, 2011, 2013a; Meyer et al. 2009; Eulaers et al. 2011a, b; Herzke et al. 2011), although concentrations may be derived to a large extent from external contamination by preen oil (Jaspers et al. 2008). Washing techniques to remove preen oil that have been tested thus far may affect the internal load in the feather (Jaspers et al. 2008, 2011). However, external contamination with preen oil may be advantageous when using feathers for contaminant monitoring. This is because total feather concentrations of organic pollutants are increased by the lipid-rich preen oil and correlations between feather and internal tissue contaminant concentrations are enhanced (Jaspers et al. 2008; Solheim 2010; Eulaers et al. 2011b). Sampling feathers is also generally easier and less invasive than sampling preen oil. The degree of contamination of feathers with preen oil partly depends on preening frequency which varies with species, season, environmental conditions, and gender (van Iersel and Bol 1958; Greichus and Greichus 1974; Caldwell et al. 2001; Pap et al. 2010).

\section{Blood, plasma and serum}

Raptors can be exposed to chemicals through inhalation, dermal contact and ingestion, although diet is considered to be the main exposure pathway for most major pollutants. Irrespective of exposure pathway, contaminants, once absorbed, are transported and distributed throughout the body via the blood. Contaminant half-lives are typically shorter in blood than in internal tissues (S.I. Table 2) and, depending on the timing of sampling relative to exposure, pollutant concentrations are generally lower and more variable than in body tissues. For lipid soluble contaminants such as POPs, low concentrations in blood are primarily related to relatively low lipid content compared to other commonly sampled tissues such as eggs and tissue (Elliott and Norstrom 1998). Overall, low contaminant concentrations in blood mean that relatively high volumes may be needed to achieve analytical detection limit and it may be necessary to obtain a greater degree of replication of samples to reduce the effects of relatively high interindividual variability.

Overall, blood concentrations provide a non-destructive measure of recent exposure to compounds (Olsson et al. 2000; Martínez-López et al. 2009; Sonne et al. 2010; Eulaers et al. 2011b) but, because half-lives are relatively short, may not be indicative of medium or long-term exposure (Morrissey et al. 2010). Despite this, correlations between blood and internal tissue concentrations have been found for some compounds (García-Fernández et al. 1995, 1996, 1997; Henriksen et al. 1998; Eagles-Smith et al. 2008) but such relationships can be disrupted by remobilization of contaminants from fat or other depots during egg laying, moult, starvation and migration (Henny and Meeker 1981; Henriksen et al. 1996; Evers et al. 2005) and by variation in either exposure pattern or intrinsic factors such as age, size, and body condition (García-Fernández et al. 1995, 1997). Blood can also be analysed for effects biomarkers such as haematological parameters (including measurement of clotting performance), oxidative stress, plasma biochemistry, enzymatic activities, and gene expression (Nyholm 1998; Martínez-López et al. 2004; Fisher 2009; Cesh et al. 2010; Martinez-Haro et al. 2011a; Rattner et al. 2011, 2014b, 2015; Espín et al. 2014b, d; Maceda-Veiga et al. 2015).

Whole blood, plasma or serum can be used for contaminant analysis. Plasma contains fibrinogen, which results in coagulation unless the sample is treated with an anticoagulant (Ehresman et al. 2007), typically heparin or ethylenediamine tetraacetic acid (EDTA). Of the studies we reviewed, 42 measured pollutant concentrations in blood (Table 2) and heparin was used in $71 \%$ and EDTA in $5 \% ; 24 \%$ did not indicate which, if any, anticoagulant was used. EDTA can be problematic as it may affect clinical chemistry analytes and enzyme measurements (Hochleithner 1994) while significant movement of $\mathrm{Pb}$ from red cells to plasma can occur (deSilva 1981). However, heparin interferes with white blood cells and 
Table 3 Advantages and disadvantages on the use of the different blood compartments for pollutant exposure monitoring of raptors

\begin{tabular}{|c|c|c|}
\hline $\begin{array}{l}\text { Blood } \\
\text { compartment }\end{array}$ & Advantages & Disadvantages \\
\hline Whole blood & $\begin{array}{l}\text { Small blood volumes can be collected } \\
\text { Allows analysis for the broadest spectrum of contaminants } \\
\text { Higher concentrations of some contaminants (decaBDE) are } \\
\text { present because of their partition to whole blood } \\
\text { compartments } \\
\text { Can be used for measurement of haematology, blood cell } \\
\text { counts and some biomarkers } \\
\text { Can be used for gene expression studies }\end{array}$ & $\begin{array}{l}\text { Anticoagulants are needed } \\
\text { Lower concentrations of some contaminants (PFASs) because } \\
\text { of cellular components } \\
\text { RNA preservatives are needed }\end{array}$ \\
\hline $\begin{array}{r}\text { Plasma/ } \\
\text { Serum }\end{array}$ & $\begin{array}{l}\text { Measurement of biochemistry, antibodies and enzymatic } \\
\text { activities } \\
\text { Higher concentrations of some contaminants (PFASs) }\end{array}$ & $\begin{array}{l}\text { Anticoagulants are needed (plasma) } \\
\text { Samples have to be centrifuged } \\
\text { Plasma/serum separation may produce loss of some } \\
\text { contaminants (decaBDE, OCs) }\end{array}$ \\
\hline $\begin{array}{l}\text { Red blood } \\
\text { cells }\end{array}$ & $\begin{array}{l}\text { Measurement of antioxidant molecules and oxidative damage } \\
\text { on lipids, proteins and DNA }\end{array}$ & $\begin{array}{l}\text { Samples have to be centrifuged } \\
\text { Erythrocytes may need to be washed using saline solution for } \\
\text { some analyses } \\
\text { Concentration of some compounds may be lower }\end{array}$ \\
\hline $\begin{array}{l}\text { Dried blood } \\
\text { spot }\end{array}$ & $\begin{array}{l}\text { Anticoagulants are not needed } \\
\text { Simplify sampling } \\
\text { Facilitate handling, storage and transport of blood samples }\end{array}$ & $\begin{array}{l}\text { Limited number of laboratories mastering sufficiently sensitive } \\
\text { methods } \\
\text { Variable amount of trace metals in the filter paper (both within } \\
\text { and between lots) and it is possible external contamination }\end{array}$ \\
\hline
\end{tabular}

sometimes with PCR analysis, although heparinised plasma or serum is the recommended matrix for the vast majority of biochemical tests (Hochleithner 1994). Studies involving gene expression requires RNA conservation with RNAlater $^{\mathrm{TM}}$ or similar preservatives (Maceda-Veiga et al. 2015).

Which blood compartment should be selected for analysis depends on the contaminant of interest and whether additional end-points (lipids, proteins, hormones) are to be measured. Advantages and disadvantages on using each compartment are summarised in Table 3. Use of whole blood may permit collection of smaller blood volumes which can be important when sampling small raptors (Volz et al. 2001). Most studies that have measured $\mathrm{Pb}$ in raptors have used whole blood (García-Fernández et al. 1995, 1997; Mateo et al. 1999; Benito et al. 1999; Pain et al. 2007; Gangoso et al. 2009; Espín et al. 2014b, d). Whole blood has also been recommended for analysing OCs and brominated flame retardants to avoid potential loss of contaminants in the cellular fraction (Volz et al. 2001; Leslie et al. 2013), although most lipid soluble contaminants are in the triglycerides present in the plasma fraction. Serum or plasma can be used for analysis of many contaminants but it is notable that concentrations of some poly- and perfluoroalkyl substances (PFASs) in whole blood are approximately half those in serum or plasma because of the volume displacement of cellular components, which do not appear to function as a sorbent for these substances (Ehresman et al. 2007). Of the 42 studies we reviewed that measured contaminant levels in raptor blood, whole blood was used in $79 \%$ (to measure metals, POPs or anticoagulant rodenticides), plasma in $17 \%$ (to analyse POPs, PFAS and pharmaceuticals), and serum in $5 \%$ (analysis of POPs).

Dried blood spots (DBSs) have been proposed as an alternative to fresh blood for monitoring chemical residues in raptors (Shlosberg et al. 2011a, b). The possibility of quantifying POPs, metals and PFASs in small $(\sim 200 \mu \mathrm{l})$ blood volumes could simplify sampling as this could be done by venepuncture with microhematocrit capillaries rather than larger syringes and so be less invasive. Moreover, DBS are likely to be easier to handle, store and transport than blood samples. However, to date, the number of laboratories with sufficiently sensitive methods to analyse DBS is limited. In addition, Stove et al. (2012) have identified several limitations to the technique, such as the presence of variable amounts of trace metals in the filter paper (within and between production batches) and possible external contamination.

In terms of expression of contaminant data, blood concentrations are typically expressed on a wet weight basis or by volume. Conversion factors (wet weight to volume) of 0.94 (whole blood) and 0.98 (plasma) have been suggested, based on relative density (Coeurdassier et al. 2012), assuming whole blood and plasma densities of 1.060 and $1.025 \mathrm{~g} \mathrm{ml}^{-1}$, respectively (Barlow and Whitehead 1928). Blood lipid levels in birds may change seasonally (deGraw et al. 1979) and with body condition (Elliott et al., 1998). 
Reporting of concentrations on both wet and lipid weight basis is recommended for lipid soluble POPs.

Overall, blood has been used to monitor concentrations of all the main priority contaminants in raptors but, in the studies we reviewed, analysis was mainly for POPs and toxic metals, particularly $\mathrm{Pb}$ (Table 2). Blood metal concentrations have been widely related to effects that range from sub-lethal (such as enzyme inhibition) through to mortality (Czirjak et al. 2010; Franson and Pain 2011; Shore et al. 2011; Wayland and Scheuhammer 2011; Espín et al. 2015) and blood may be particularly useful for monitoring $\mathrm{Hg}$ in raptors (Henny and Elliott 2007; Guigueno et al. 2012). This is because, as with eggs, $\mathrm{Hg}$ in blood is almost entirely present as $\mathrm{MeHg}$ (DesGranges et al. 1998; Fournier et al. 2002; Rimmer et al. 2005) and total $\mathrm{Hg}$ can be used as a [cheaper] surrogate measure for MeHg (Eagles-Smith et al. 2008); Hg concentrations in blood are highly correlated with $\mathrm{MeHg}$ in liver (Henny et al. 2002).

\section{Internal tissues}

Pollutant concentrations in internal tissues are a key indicator of bioaccumulation. Tissue samples are collected across some 20 countries in Europe (Table 1, S.I. Fig. 1), but is only possible where carcasses are found in the field or injured birds are euthanasied for welfare reasons. Which specific internal tissue should be analysed for contaminants depends in part on the endpoint of the study, the toxicokinetics of the compounds of interest (García-Fernández et al. 2008) and the target organ for toxicity. Pollutant concentrations associated with adverse effects in target organs, or with specific endpoints such as mortality and reproduction, have been extensively reported (Beyer and Meador 2011). However, tissues which accumulate the highest contaminant concentrations and/or multiple contaminants that can be determined simultaneously are sometimes analysed in preference to the target organ. In our review of 249 European studies, 111 analysed internal tissues and the liver was by far the most commonly analysed organ (98 studies, Table 2). In some cases, internal tissues are collected specifically for the determination of effect biomarkers (Mateo et al. 2003; Rainio et al. 2012) but these are labile, must be measured or conserved immediately after biopsy or death (Mateo et al. 2003; Rainio et al. 2012) and cannot be measured in tissues from carcasses found in the field some time after death.

Post-mortem decomposition and cause of death can both potentially affect tissue contaminant concentrations. Decomposition may lead to desiccation of tissues and microbial post-mortem metabolism of contaminants (Ferner 2008; Butzbach 2010). Although time of death can be estimated (Payne-James et al. 2003), we are unaware of verified methods that can be used to normalise contaminant concentrations for extent of decomposition. Cause of death can alter tissue contaminant concentrations in that starvation can deplete adipose tissue. The associated metabolism of fat leads to remobilisation of lipophilic compounds which are subsequently distributed via the bloodstream to highly metabolically active organs such as the liver (Hela et al. 2006). This can result in elevated liver contaminant concentrations, an effect exacerbated by starvation-induced liver wastage (Wienburg and Shore 2004; Crosse et al. 2013). Body condition can be quantified during necropsy (Espín et al. 2014a) and either included as a variable in any statistical comparisons of contaminant data, or used as a factor to focus sample selection so that source of variance is minimised (for example, Elliott et al. 2015).

Pollutant concentrations in internal organs are expressed on a wet, dry or lipid weight basis and this variability can hamper inter-study comparisons (Henny and Elliott 2007). In general, metal concentrations are reported on dry weight basis to avoid spurious variation caused by differences in water content between samples. Concentrations of lipophilic pollutants are often reported on a wet weight or lipid weight basis to normalise for inter-individual and interspecies variation in organ lipid content. Wet concentrations can be converted to a dry weight and lipid weight basis (S.I. Document 4) but the water and lipid content of tissues must be known.

In terms of analysis of particular compound groups, organic contaminants typically bioaccumulate strongly in adipose fat depots and in those body tissues with relatively high lipid content, such as liver, kidney, muscle and brain (Borlakoglu et al. 1991; Buckman et al. 2004; Voorspoels et al. 2006; Espín et al. 2010a). Partitioning between tissue types varies with physico-chemical properties and compounds with $\log \mathrm{K}_{\mathrm{ow}}<3.3$ have a higher affinity for phosphatidylcholine while those with $\log \mathrm{K}_{\mathrm{ow}}>3.3$ partition preferentially accumulate into trioleoylglycerol (Sandermann 2003). This may account for why more polar OCs (for example lindane- $\gamma-\mathrm{HCH}$ ) preferentially accumulate in tissues like the brain which contains high concentrations of more polar lipids such as phospholipids. Non-polar compounds (for example DDTs and PCBs) are mainly accumulated in organs such as liver or adipose tissue that contain high proportion of triglycerides (Kawai et al. 1988; Noble and Cocchi 1990; Sandermann 2003; Maervoet et al. 2005). Overall though, the highest absolute concentrations of many non-polar organic compounds are found in fat (María-Mojica et al. 2000; Kenntner et al. 2003b; Espín et al. 2010a), probably reflecting the affinity of these compounds for triglycerides. Therefore, when carcasses are available, adipose tissue can be useful for monitoring chronic exposure (Kenntner et al. 2003b; Hela et al. 2006), although only $9 \%$ of 137 studies on POPs that we reviewed reported 
concentrations in fat (Table 2). This may be partly because sampling fat can be difficult when carcasses are partially decomposed or when body condition is poor.

Liver POP concentrations often reflect recent dietary exposure (Newton et al. 1993; Kenntner et al. 2003b; van Drooge et al. 2008), although concentrations of lipophilic compounds can be elevated by redistribution of compounds from depleting fat stores (Kenntner et al. 2003a; Wienburg and Shore 2004; Crosse et al. 2013). Less lipophilic compounds such as PFASs also accumulate in liver [and other soft tissues] where they bind to protein albumin (Jones et al. 2003; Yoo et al. 2009; Stahl et al. 2011). Studies in leghorn chickens (Gallus gallus) suggest that the highest concentrations of perfluorooctane sulfonate (PFOS) and perfluorooctanoic acid (PFOA), two PFASs widely used in industry (ATSDR 2009), occur in the liver and kidney, respectively (Yoo et al. 2009). Liver concentrations for a range of organic contaminants can be related to those estimated to be indicative of adverse effects (Blus 2011; Elliott and Bishop 2011; Harris and Elliott 2011), while effects on cytochrome P450 activity and antioxidant enzymes in individuals can be measured directly if samples are fresh (Helgason et al. 2010). However, when the primary interest concerns the assessment of POP-induced effects, analysis of the brain can be informative as it is a major target organ and concentrations associated with mortality and chronic effects have been defined for various compounds (Blus 2011; Elliott and Bishop 2011; Harris and Elliott 2011). However, the brain was analysed in only about $5 \%$ of the POPs studies that we reviewed (Table 2). This is maybe because, in more recent years, lethal exposure to POPs is rarely encountered and, furthermore, excision of an intact brain from a bird skull is time consuming compared with removal of other tissues such as the liver.

The liver and kidneys are the internal organs most typically used for analysis of metals. Approximately $30-45 \%$ of studies in which $\mathrm{Pb}, \mathrm{Cd}$ and/or $\mathrm{Hg}$ were determined involved analysis of these organs (Table 2); $\mathrm{Pb}$ is also often analysed in bone ( $24 \%$ of studies). The relative distribution of these metals between different body tissues differs markedly.

$\mathrm{Pb}$ follows a tri-compartmental kinetic model where bone is the principle organ of accumulation (García-Fernández et al. 1997), but there is also distribution to other major organs, primarily liver, kidney and also brain (Custer et al. 1984; Franson and Pain 2011). Pb concentrations tend to be higher in the kidneys than in the liver and highest in bone when exposure is chronic or less recent (GarcíaFernández et al. 1995) and often highest in the liver at acute poisoning (e.g. Helander et al. 2009). Overall, bone $\mathrm{Pb}$ reflects lifetime accumulation while soft tissue and blood residues are indicative of, and can be used to monitor, shorter-term exposure (García-Fernández et al. 1995, 1997). Threshold concentrations in these organs for adverse effects have been suggested for Falconiformes (Franson and Pain 2011).

The distribution of Cd between body tissues is dose-dependent (Scheuhammer 1987). The kidney is the main organ for accumulation during chronic exposure to low concentrations, but accumulation is greater in liver following acute exposure to high doses (García-Fernández et al. 1995, 1996). The liver:kidney $\mathrm{Cd}$ concentration ratio can thus be used as an indicator of exposure pattern (Scheuhammer 1987). Nevertheless, in contaminated areas, liver $\mathrm{Cd}$ may be the better indicator of chronic exposure since kidney concentrations fall significantly with onset of Cd-induced tubular dysfunction (Scheuhammer 1987) and so may not be representative of the true levels of exposure. Normally though, $\mathrm{Cd}$ concentrations in birds are at least two orders of magnitude below concentrations associated with clinicallymanifest kidney damage (Wayland and Scheuhammer 2011) and, in such habitats, the kidney may be a more useful monitor of exposure as concentrations are likely to be higher and more likely to exceed analytical limits of detection.

For $\mathrm{Hg}$, the highest tissue concentrations are found in the kidney and liver, followed by muscle and brain (Norheim and Frøslie 1978; Holt et al. 1979; Häkkinen and Häsänen 1980; Kalisinska et al. 2014). How Hg partitions between internal organs depends on whether exposure is to organic or inorganic forms of the metal, and the Hg kidney:liver molar ratio has been proposed as a mean of distinguishing between chronic exposure to $\mathrm{MeHg}$ and inorganic Hg (Scheuhammer 1987). Kidney:liver molar ratios much higher than 1 reflect exposure to inorganic $\mathrm{Hg}$, whereas a ratio closer to 1 (and $<2$ ) is characteristic for exposure to $\mathrm{MeHg}$. In general, the liver and/or the kidney can be used for monitoring trends in exposure. Threshold liver and kidney concentrations associated with adverse effects in birds generally have been suggested (Shore et al. 2011) but interpretation of internal tissue concentrations is problematic. This is because of demethylation processes and sequestration of selenium (Se) bound inorganic $\mathrm{Hg}$ (Henny et al. 2002; Eagles-Smith et al. 2008), Se forming a complex with $\mathrm{Hg}$ and protecting against $\mathrm{Hg}$ toxicity (Scheuhammer 1987; Cuvin-Aralar and Furness 1991; Scheuhammer et al. 2008). Ideally, total $\mathrm{Hg}$, $\mathrm{MeHg}$ and $\mathrm{Se}$ concentrations should be measured simultaneously and analysis of both liver and kidney can provide information on the nature of exposure.

Of the remaining priority compounds outlined in the current paper, the liver is the tissue which is almost always used for analysis of anticoagulant rodenticides (Table 2; Rattner et al. 2014a). These, and in particular the secondgeneration anticoagulant rodenticides, are sequestered by high affinity binding sites in the liver (Huckle et al. 1989; 
Vandenbroucke et al. 2008; Fisher 2009). Liver half-lives vary between compounds (Vandenbroucke et al. 2008; S.I. Table 2) but, overall, liver concentrations provide a signal of single or multiple exposures integrated over periods of weeks and months (Shore et al. 2015). Rodenticide concentrations tend to be higher in liver than in other tissues (Huckle et al. 1988, 1989) and extent of rodenticide use, diet, resistance in rodents and physiology can all affect the magnitude of residues accumulated by raptors (Shore et al. 2015). There is no clear diagnostic or threshold liver concentration that is associated with mortality but higher residues are associated with a greater probability of mortality (Thomas et al. 2011).

\section{Other sample matrices}

Although less frequently used, other matrices such as crop contents, regurgitated pellets, excrement, preen oil and talons can be analysed for contaminants. Recommendations on sampling methods are given by Espín et al. (2014a).

Crop contents can be obtained from carcasses and regurgitated pellets from roost and nest sites. Both provide information about spatio-temporal variation in diet which can be important when assessing likely exposure of raptors to contaminants (Mañosa et al. 2003; van Drooge et al. 2008). Crop (and gizzard/stomach) contents have been used to determine exposure to anticoagulant rodenticides (Ruder et al. 2011) and to confirm the occurrence of lethal poisoning by organophosphate and carbamate insecticides (Elliott et al., 1996; 1997) and compounds such as strychnine, metaldehyde and paraquat (Berny 2007). Regurgitated pellets are frequently used in dietary studies (Love et al. 2000; Redpath et al. 2001; Terraube et al. 2011; Trierweiler and Hegemann 2011) and are widely collected across Europe by numerous raptor population monitoring schemes (Table 1, S.I. Fig. 1). Pellets also have characteristics that make them well-suited for use as non-invasive indicators of environmental contaminants. These include that a large number of samples can be obtained, samples can be collected from species that are difficult to trap or that are rarely found as carcasses, and pellets can be collected regardless of the age or gender of the bird or of season. Pellets have been used to measure exposure of raptors to toxic metals (Bostan et al. 2007; Lopes et al. 2010) including Pb from shot, the presence of which can be confirmed by X-rays (Mateo et al. 2001; Pain et al. 2007). Chemical analysis has also been used to assess exposure of owls to second-generation anticoagulant rodenticides (Gray et al. 1994; Newton et al. 1994; Eadsforth et al. 1996) and regurgitated barn owls (Tyto alba) pellets were estimated to contain 25-29\% of ingested dose (Gray et al. 1992, 1994; Newton et al. 1994).

Sampling of excrement can be either minimally invasive or non-invasive as fresh samples can be obtained by inducing birds to defecate when they are being handled or by collecting faeces from around nests and roosts. Large amounts of sample can normally be obtained quickly, although DNA analysis may be needed to identify the species and/or individual that produced the sample (Cheung et al. 2009). Excrement has been used in studies on diet composition, hormones and genetics (Goymann and Jenni-Eiermann 2005; Waits and Paetkau 2005; Carlisle and Holberton 2006; Reynolds et al. 2006) and when measuring effects biomarkers such as porphyrins (Akins et al. 1993; Mateo et al. 2006; Martinez-Haro et al. 2011b). While there have been a number of avian contaminant studies that have analysed faecal material, they have generally not been on raptors (Howald 1997; Beyer et al. 1998; Dauwe et al. 2000; Sun and Xie 2001; Sun et al. 2005, 2006; Yin et al. 2008; Costa et al. 2012; Berglund et al. 2015). Contaminant concentrations in excrement have been considered particularly useful as an indicator of exposure to contaminants that are poorly absorbed across the gut. Such compounds include nonessential metals (Dauwe et al. 2000, 2004; Morrissey et al. 2005), which are typically present in higher (and more easily detected) concentrations in excrement than in food items (Morrissey et al. 2005; Yin et al. 2008). However, there appears to be a lack of any direct relationship between concentrations in faeces and in internal tissues for the majority of metals, suggesting that faecal measurements may not be a suitable proxy for accumulation (Berglund et al. 2011).

In contrast to faeces, preen oil provides information about pollutants that have been absorbed into the body. It is an oily secretion of waxes from the uropygial gland, a sebaceous gland at the base of the tail feathers. Birds use this oil when preening to protect and waterproof their feathers (Solheim 2010). Collection of preen oil can be considered non-invasive when sampled from carcasses and minimally invasive when collected from living birds as it is necessary to press the gland softly to expel the oil (Espín et al. 2014a). To date, preen oil is only rarely collected by raptor monitoring schemes in Europe (Table 1, S.I. Fig. 1) and can sometimes be difficult to sample in sufficient quantity for analysis, particularly from nestlings (Eulaers et al. 2011b). Uropygial secretion quantity and composition also varies between species (Campagna et al. 2011; GarcíaFernández et al. 2013a). The oil can contain high concentrations of lipophilic pollutants (van Den Brink 1997; Yamashita et al. 2007; Jaspers et al. 2008, 2011; Eulaers et al. 2011b), which is related to its high lipid content (87 \% lipid content, Eulaers et al. 2011b), and is considered an excretion route for lipophilic compounds (Solheim 2010). Contaminant concentrations in preen oil are correlated with those in internal tissues (van Den Brink 1997; Eulaers et al. 2011b), but compound profiles can differ. For example, preen oil is relatively richer in lower-chlorinated PCB congeners (di-, tri-, and tetra-CB) than internal tissues 
(Larsson and Lindegren 1987; Yamashita et al. 2007; Jaspers et al. 2013b).

Clipped talons are keratinized tissues that, during their formation, can accumulate certain contaminants. To our knowledge, only Hopkins et al. (2007) have used talons to analyse contaminant concentrations in bird species. They found $\mathrm{Hg}$ concentrations in clipped talons from ospreys (Pandion haliaetus) were correlated with concentrations in internal tissues and the association was stronger than that between feathers and soft tissues. This was believed to be because talons, unlike feathers, grow continuously, and talon $\mathrm{Hg}$ concentrations are more likely to be representative than feathers of the current $\mathrm{Hg}$ body pool. Hopkins et al. (2007) collected a limited portion of talon $(5 \mathrm{~mm}$ length from digits 2 and 3 on the left foot) without disturbing the talon's blood supply but it is arguable as to whether this could be classed as a non-invasive sample as talons are important for catching, holding and processing prey, and clipping the talons of live wild raptors may adversely affect hunting performance. Collection from carcasses is possible but may only be advantageous when internal organs are too decomposed for analysis.

\section{Monitoring other contaminants of current and emerging concern}

This review has focussed on the suitability of different matrices for the compounds that are most commonly monitored across Europe. However, there are also other current and emerging compound groups of concern either in terms of general environmental contamination or as a direct threat to raptors themselves.

Pharmaceuticals and personal care products, including human and veterinary drugs, fragrances, and cosmetics, are produced in high volumes and are widely used (Rüdel et al. 2006; Nakata et al. 2007). Some compounds, such as synthetic musks, are highly lipophilic and have been detected in several aquatic organisms (Nakata et al. 2007), and pharmaceuticals generally have been detected in the environment across the world (Boxall et al. 2012). There is also growing concern over the potential ecotoxicological effects of releasing veterinary pharmaceuticals from animal feed lot operations into streams and estuaries (Daughton and Ternes 1999; Kolpin et al. 2002). The potential for monitoring environmental concentrations of pharmaceuticals using raptors has recently been investigated in ospreys (Pandion haliaetus) (Lazarus et al. 2015), and has been more widely considered by Shore et al. (2014), but generally data remain scarce. Two exceptions however are non-steroidal anti-inflammatory drugs (NSAIDs) such as e.g. diclofenac, and veterinary drugs used as antiparasitics (organophosphate and carbamate compounds) or to euthanase animals (e.g., barbiturates).
NSAIDs have been studied most intensively in raptors because of their catastrophic impacts on vulture populations (Green et al. 2004, 2006, 2007; Oaks et al. 2004; Naidoo et al. 2009; Sharma et al. 2014; Galligan et al. 2014; Cuthbert et al. 2014; Zorrilla et al. 2015). This work has focussed largely on Asian and African populations although, in Spain, a wild Griffon vulture (Gyps fulvus) has been found to be exposed to and apparently killed by the NSAID flunixin (Zorrilla et al. 2015), and other pharmaceuticals have been detected in other individuals (GarcíaFernández et al. 2013b). NSAIDs bind strongly to plasma protein and are metabolised mainly in the liver, usually to inactive compounds (Lees et al. 2004). Plasma, liver and kidney can all be used to monitor NSAID exposure and can also be used for effects assessment, since diclofenac-treated vultures have shown an increase in plasmatic uric acid, alanine transferase and glutamic pyruvate transaminase, and histopathological changes in kidneys and liver (Swan et al. 2006; Jain et al. 2009); visceral gout has also been a key indicator of exposure (Cuthbert et al. 2015). Data regarding the safety of other NSAIDs and risks to other species is currently limited (Taggart et al. 2009; GarcíaFernández 2014; Sharma et al. 2014); and further monitoring of NSAIDs concentrations in raptor populations and evaluation of potential effects therefore remains a priority.

Organophosphate (OP) and carbamate (CB) compounds are used as antiparasitics in livestock and secondary exposure can result in raptor mortalities (Henny et al. 1985; Mineau et al. 1999). These compounds are rapidly metabolized in the body and so the proventriculus, gizzard or gastrointestinal content are the samples commonly used to determine exposure, although residues have been also detected in liver, brain and muscle (Hamilton and Stanley 1975; Glaser 1999; Berny 2007; Shimshoni et al. 2012; Mateo et al. 2015). The toxicity of OP and CB pesticides is mainly due to the disruption of the nervous system by inhibition of cholinesterase (ChE) enzymes activity (Glaser 1999; Hill 2003), and measurement of brain ChE in dead birds and plasma/serum ChE activity in live birds is also used as biomarker to monitor exposure (Elliott et al., 1996; 1997; Martínez-Haro et al. 2007; Shimshoni et al. 2012). Among other veterinary drugs of concern, barbiturates, of which pentobarbital is the predominant active component, are commonly used to euthanize domestic animals (Aldeguer et al. 2009). Secondary barbiturate poisoning has been reported in raptors (Shore et al. 2014) and pentobarbital and, some other euthanasia drugs, can be detected by analysis of the liver or upper gastrointestinal contents. Detection of residues in the liver provides more definitive evidence that a drug has been absorbed from the ingesta, as do blood samples from live birds (Thomas 1999).

A newer class of insecticides now in prevalent use worldwide and which has attracted attention because of 
risk to pollinators (Rundlöf et al. 2015), aquatic organisms (Morrissey et al. 2015) and insectivorous birds (Mineau and Palmer 2013; Hallmann et al. 2014) are the neonicotinoid pesticides. These insecticides act as agonists of the insect nicotinic acetylcholine receptors (AChRs) (Gibbons et al. 2014) and raptor prey species that feed on seed and crops may be exposed to these pesticides. Experimental studies have shown that neonicotinoid pesticides may produce adverse effects on reproduction, behaviour, immune system, growth and development in birds (Cox 2001; Mineau and Palmer 2013; Tokumoto et al. 2013; Lopez-Antia et al. 2013, 2015) but little is known about the exposure in top predators, including raptors. The liver and crop content can be analysed to determine exposure to neonicotinoid pesticides in dead birds (Lopez-Antia et al. 2015), and it may be possible to use blood as a non-destructive sample to determine exposure, as has recently been demonstrated in humans (Mohamed et al. 2009; Yeter and Aydin 2014; Yamamuro et al. 2014). Experimental studies on rats have shown that the neonicotinoid imidacloprid inhibits $\delta$-ALAD activity in liver tissue (Sauer et al. 2014), causes changes in antioxidant enzymes in brain and liver, and increases lipid peroxidation in plasma, brain and liver (El-Gendy et al. 2010; Duzguner and Erdogan 2012) while red-legged partridges (Alectoris rufa) exposed to imidacloprid suffered sublethal effects including altered biochemical parameters in plasma and oxidative stress in red blood cells (Lopez-Antia et al. 2013). Therefore, blood, liver and brain can be used for monitoring both exposure and effects from these compounds. None of the programmes surveyed by Gómez-Ramírez et al. (2014) specified that they monitored exposure to neonicotinoids in raptors but such monitoring would help determine if there may be any significant food-chain transfer and exposure in raptors.

\section{Conclusions}

In this paper, we have reviewed the merits of different sample matrices for measuring environmental contaminants in raptors. There is no optimal all-purpose tissue. The scientific relevance of each sample type depends on the aims and objectives of any study and the compound(s) of interest, but we have attempted to show the relative merits of each matrix for major groups of contaminants. Of all the matrices, blood and liver are probably used most extensively for determining recent and longer-term exposure, respectively. However, blood samples are less widely and frequently collected across Europe than several other matrices (Table 1) and volume size and storage requirements are likely to limit the number of analyses that can be conducted. Internal tissue and carcass collection is conducted by more schemes than for blood but in fewer countries (Table 1), and we have no information on the relative numbers of each tissue type collected or their typical condition. Where blood and/or liver can be collected, they are likely to be the most useful for monitoring but developing techniques for a wider range of matrices is merited so that use of limited blood and liver samples can be focussed towards compounds where use of other matrices is not appropriate. This may require greater use of material that to date is widely collected but relatively little analysed, such as food remains and regurgitated pellets (Tables 1 and 2), and enhanced routine collection of other samples, such as preen oil. The potential of such samples may increase in the future as analytical sensitivity and understanding of contaminant toxicokinetics further improves.

Although a wide range of samples are collected across Europe, (failed) eggs and feathers are the two matrices for which collection effort appears to be greatest (Table 1). These may provide the best opportunities for instigating widescale (pan-continental) monitoring, although neither is suitable for all contaminants. Eggs are already widely used and critical concentrations have been suggested for various compounds (Beyer and Meador 2011) but data need to be reported in a harmonised way (for example, correcting for desiccation). Recently grown feathers can be used for determining metals, and potentially for organic contaminants because of the presence of preen oil on the feathers, but methodologies to distinguish external from internal contamination need to be employed and care taken in interpreting resultant data. A further major challenge for large-scale monitoring using any matrix is that samples are unlikely to be available for the same species over a range of habitats across large spatial areas. Approaches using species guilds, where guilds are defined by similarity in trophic strategy, may be needed to obtain such coverage. Developing this concept, and the data needed to characterise the within-guild read-across between species for specific sample matrices, together with better harmonisation between analytical laboratories to ensure data comparability, are perhaps the next steps needed to develop widescale contaminant monitoring using raptors.

Acknowledgments This article is an output from a workshop on Setting Best Practices on Raptor Contaminant Monitoring Activities in Europe, one of the activities of the EURAPMON network (http:// www.eurapmon.net) hosted in Murcia in May-June 2013. EURAPMON is a Research Networking Programme funded through the European Science Foundation (ESF). The work undertaken for this review was also supported by EURAPMON-funded short exchange visits awarded to Antonio J. García-Fernández and Silvia Espín who travelled to work with other coauthors in formulating this manuscript. García-Fernández AJ, Herzke D, Shore RF, van Hattum B and Martínez-López E participated as core group in the preparation of the manuscript. Coeurdassier M, Eulaers I, Fritsch C, Gómez-Ramírez P, 
Jaspers $\mathrm{V}$ and Krone $\mathrm{O}$ were participants in the workshop in alphabetical order and collaborated in the writing of the manuscript (equal contribution); and Duke G, Helander B, Mateo R, Movalli P, Sonne C and van den Brink NW collaborated in the final writing of the manuscript as well (equal contribution).

\section{Compliance with ethical standards}

Conflict of Interest The authors declare that they have no conflict of interest.

Informed consent Informed consent was obtained from all individual participants included in the study.

Open Access This article is distributed under the terms of the Creative Commons Attribution 4.0 International License (http://crea tivecommons.org/licenses/by/4.0/), which permits unrestricted use, distribution, and reproduction in any medium, provided you give appropriate credit to the original author(s) and the source, provide a link to the Creative Commons license, and indicate if changes were made.

\section{References}

Ackerman JT, Herzog MP, Schwarzbach SE (2013) Methylmercury is the predominant form of mercury in bird eggs: a synthesis. Environ Sci Technol 47:2052-2060. doi:10.1021/es304385y

Agusa T, Matsumoto T, Ikemoto T et al (2005) Body distribution of trace elements in black-tailed gulls from Rishiri Island, Japan: age-dependent accumulation and transfer to feathers and eggs. Environ Toxicol Chem 24:2107-2120

Akins JM, Hooper MJ, Miller H, Woods JS (1993) Porphyrin profiles in the nestling European starling (Sturnus vulgaris): a potential biomarker of field contaminant exposure. J Toxicol Environ Health 40:47-59. doi:10.1080/15287399309531775

Aldeguer MP, Talavera V, María-Mojica P et al (2009) Barbiturate poisoning in carrion feeders consuming carcasses from equine euthanized with Dolethal ${ }^{\circledR}$. Rev Toxicol 26:58

ATSDR (2009) Toxicological profile for perfluoroalkyls. Public Health Service, Agency for Toxic Substances and Disease Registry, U.S

Barlow OW, Whitehead RW (1928) The relation of the blood specific gravity to the cell count, hemoglobin level, cell volume and total blood volume in pigeons. Am J Physiol 87:51-57

Becker PH, Sperveslage H (1989) Organochlorines and heavy metals in Herring Gull (Larus argentatus) eggs and chicks from the same clutch. Bull Environ Contam Toxicol 42:721-727. doi:10. 1007/BF01700394

Behrooz RD, Esmaili-Sari A, Ghasempouri SM et al (2009) Organochlorine pesticide and polychlorinated biphenyl residues in feathers of birds from different trophic levels of South-West Iran. Environ Int 35:285-290. doi:10.1016/j.envint.2008.07.001

Benito V, Devesa V, Muñoz O et al (1999) Trace elements in blood collected from birds feeding in the area around Doñana National Park affected by the toxic spill from the Aznalcóllar mine. Sci Total Environ 242:309-323

Berglund ÅMM, Koivula MJ, Eeva T (2011) Species- and age-related variation in metal exposure and accumulation of two passerine bird species. Environ Pollut 159:2368-2374. doi:10.1016/j. envpol.2011.07.001

Berglund ÅMM, Rainio MJ, Eeva T (2015) Temporal trends in metal pollution: using bird excrement as indicator. PLoS ONE 10:e0117071. doi:10.1371/journal.pone.0117071
Berny P (2007) Pesticides and the intoxication of wild animals. J Vet Pharmacol Ther 30:93-100. doi:10.1111/j.1365-2885.2007. 00836.x

Best DA, Elliott KH, Bowerman WW et al (2010) Productivity, embryo and eggshell characteristics and contaminants in bald eagles from the Great Lakes, U.S.A. Environ Toxicol Chem 29:1581-1592

Beyer WN, Meador JP (2011) Environmental contaminants in biota: interpreting tissue concentrations. CRC Press, Boca Raton, FL

Beyer WN, Audet DJ, Morton A et al (1998) Lead exposure of waterfowl ingesting Coeur d'Alene river basin sediments. J Environ Qual 27:1533-1538. doi:10.2134/jeq1998. $00472425002700060033 x$

Blanco G, Frías O, Jiménez B, Gómez G (2003) Factors influencing variability and potential uptake routes of heavy metals in black kites exposed to emissions from a solid-waste incinerator. Environ Toxicol Chem 22:2711-2718

Blus LJ (2011) DDT, DDD and DDE in birds. In: Beyer WN, Meador JP (eds) Environmental contaminants in biota: interpreting tissue concentrations. CRC Press, Taylor \& Francis, Boca Raton, pp $425-447$

Bonnet X, Bradshaw Don, Shine R (1998) Capital versus income breeding: an ectothermic perspective. Oikos 83:333-342. doi:10. $2307 / 3546846$

Borg K, Wanntorp H, Erne K, Hanko E (1969) Alkyl mercury poisoning in terrestrial Swedish wildlife. Viltrevy. Almqvist och Wiksell, Uppsala, pp 301-379

Borlakoglu JT, Wilkins JP, Dils RR (1991) Distribution and elimination in vivo of polychlorinated biphenyl (PCB) isomers and congeners in the pigeon. Xenobiotica 21:433-445. doi:10. 3109/00498259109039483

Bortolotti GR (2010) Flaws and pitfalls in the chemical analysis of feathers: bad news-good news for avian chemoecology and toxicology. Ecol Appl 20:1766-1774. doi:10.1890/09-1473.1

Bortolotti GR, Marchant TA, Blas J, German T (2008) Corticosterone in feathers is a long-term, integrated measure of avian stress physiology. Funct Ecol 22:494-500. doi:10.1111/j.1365-2435. 2008.01387.x

Bostan N, Ashraf M, Mumtaz AS, Ahmad I (2007) Diagnosis of heavy metal contamination in agro-ecology of Gujranwala, Pakistan using cattle egret (Bubulcus ibis) as bioindicator. Ecotoxicology 16:247-251. doi:10.1007/s10646-006-0124-y

Bourgeon S, Leat EHK, Magnusdóttir E et al (2012) Individual variation in biomarkers of health: influence of persistent organic pollutants in Great skuas (Stercorarius skua) breeding at different geographical locations. Environ Res 118:31-39. doi:10.1016/j.envres.2012.08.004

Boxall ABA, Rudd MA, Brooks BW et al (2012) Pharmaceuticals and personal care products in the environment: what are the big questions? Environ Health Perspect 120:1221-1229. doi:10. 1289/ehp.1104477

Buckman AH, Norstrom RJ, Hobson KA et al (2004) Organochlorine contaminants in seven species of Arctic seabirds from northern Baffin Bay. Environ Pollut 128:327-338. doi:10.1016/j.envpol. 2003.09.017

Burger J (1993) Metals in avian feathers: bioindicators of environmental pollution. Rev Environ Toxicol 5:203-311

Burger J, Gochfeld M (2001) Metal levels in feathers of cormorants, flamingos and gulls from the coast of Namibia in southern Africa. Environ Monit Assess 69:195-203

Burger J, Rodgers JA Jr, Gochfeld M (1993) Heavy metal and selenium levels in endangered wood storks Mycteria americana from nesting colonies in Florida and Costa Rica. Arch Environ Contam Toxicol 24:417-420

Bustnes JO, Folstad I, Erikstad KE et al (2002) Blood concentration of organochlorine pollutants and wing feather asymmetry in 
Glaucous Gulls. Funct Ecol 16:617-622. doi:10.1046/j.13652435.2002.00656.x

Butzbach DM (2010) The influence of putrefaction and sample storage on post-mortem toxicology results. Forensic Sci Med Pathol 6:35-45. doi:10.1007/s12024-009-9130-8

Caldwell DY, Moore RW, Caldwell DJ, Hargis BM (2001) Effect of photointensity, sound intensity, and ambient temperature on preening behavior and ingestion of spray-applied biologics. J Appl Poult Res 10:99-106

Campagna S, Mardon J, Celerier A, Bonadonna F (2011) Potential semiochemical molecules from birds: a practical and comprehensive compilation of the last 20 years studies. Chem Senses. doi:10.1093/chemse/bjr067

Cardiel IE, Taggart MA, Mateo R (2011) Using $\mathrm{Pb}-\mathrm{Al}$ ratios to discriminate between internal and external deposition of $\mathrm{Pb}$ in feathers. Ecotoxicol Environ Saf 74:911-917. doi:10.1016/j. ecoenv.2010.12.015

Carlisle JD, Holberton RL (2006) Relative efficiency of fecal versus regurgitated samples for assessing diet and the deleterious effects of a tartar emetic on migratory birds. J Field Ornithol 77:126-135. doi:10.1111/j.1557-9263.2006.00032.x

Cesh L, Elliott KH, McKinney M et al (2010) Polyhalogenated aromatic hydrocarbons and metabolites: relation to circulating thyroid hormone and retinol in nestling bald eagles (Haliaeetus leucocephalus). Environ Toxicol Chem 29:1301-1311

Cheung PP, Leung YHC, Chow C-K et al (2009) Identifying the species origin of faecal droppings used for avian influenza virus surveillance in wild birds. J Clin Virol 46:90-93. doi:10.1016/j. jcv.2009.06.016

Coeurdassier M, Fritsch C, Faivre B et al (2012) Partitioning of Cd and $\mathrm{Pb}$ in the blood of European blackbirds (Turdus merula) from a smelter contaminated site and use for biomonitoring. Chemosphere 87:1368-1373. doi:10.1016/j.chemosphere.2012. 02.031

Cortinovis S, Galassi S, Melone G et al (2008) Organochlorine contamination in the Great Crested Grebe (Podiceps cristatus): effects on eggshell thickness and egg steroid levels. Chemosphere 73:320-325. doi:10.1016/j.chemosphere.2008.05.071

Costa RA, Eeva T, Eira C et al (2012) Trace elements in faeces of great tit nestlings in relation to breeding performance in coastal areas in central Portugal. Arch Environ Contam Toxicol 63:594-600. doi:10.1007/s00244-012-9798-8

Covaci A, Harrad S, Abdallah MA-E et al (2011) Novel brominated flame retardants: a review of their analysis, environmental fate and behaviour. Environ Int 37:532-556. doi:10.1016/j.envint. 2010.11.007

Cox C (2001) Insecticide factsheet: imidacloprid. J Pestic Reform $21: 15-21$

Crosse JD, Shore RF, Wadsworth RA et al (2012) Long-term trends in PBDEs in sparrowhawk (Accipiter nisus) eggs indicate sustained contamination of UK terrestrial ecosystems. Environ Sci Technol 46:13504-13511. doi:10.1021/es303550f

Crosse JD, Shore RF, Jones KC, Pereira MG (2013) Key factors affecting liver PBDE concentrations in sparrowhawks (Accipiter nisus). Environ Pollut 177:171-176. doi:10.1016/j.envpol.2013. 02.006

Custer TW, Franson JC, Pattee OH (1984) Tissue lead distribution and hematologic effects in American kestrels (Falco sparverius L.) fed biologically incorporated lead. J Wildl Dis 20:39-43

Cuthbert R, Taggart MA, Prakash V et al (2011) Effectiveness of action in India to reduce exposure of Gyps vultures to the toxic veterinary drug diclofenac. PLoS ONE 6:e19069. doi:10.1371/ journal.pone.0019069

Cuthbert RJ, Taggart MA, Prakash V et al (2014) Avian scavengers and the threat from veterinary pharmaceuticals. Philos Trans R Soc Lond B 369:20130574. doi:10.1098/rstb.2013.0574
Cuthbert RJ, Taggart MA, Saini M et al (2015) Continuing mortality of vultures in India associated with illegal veterinary use of diclofenac and a potential threat from nimesulide. Oryx FirstView 1-9. doi:10.1017/S003060531500037X

Cuvin-Aralar ML, Furness RW (1991) Mercury and selenium interaction: a review. Ecotoxicol Environ Saf 21:348-364

Czirjak GA, Kenntner N, Oliver K (2010) Effect of blood lead levels on the constitutive immune response in white-tailed sea eagle (Haliaeetus albicilla) nestlings. Abstract book of the European wildlife disease association conference "Healthy wildlife, healthy people", Vlieland, The Netherlands

Daughton CG, Ternes TA (1999) Pharmaceuticals and personal care products in the environment: agents of subtle change? Environ Health Perspect 107:907-938

Dauwe T, Bervoets L, Blust R et al (1999) Are eggshells and egg contents of great and blue tits suitable as indicators of heavy metal pollution? Belg J Zool 129:439-447

Dauwe T, Bervoets L, Blust R et al (2000) Can excrement and feathers of nestling songbirds be used as biomonitors for heavy metal pollution? Arch Environ Contam Toxicol 39:541-546

Dauwe T, Bervoets L, Blust R, Eens M (2002) Tissue levels of lead in experimentally exposed zebra finches (Taeniopygia guttata) with particular attention on the use of feathers as biomonitors. Arch Environ Contam Toxicol 42:88-92. doi:10.1007/s002440010295

Dauwe T, Bervoets L, Pinxten R et al (2003) Variation of heavy metals within and among feathers of birds of prey: effects of molt and external contamination. Environ Pollut 124:429-436

Dauwe T, Janssens E, Bervoets L et al (2004) Relationships between metal concentrations in great tit nestlings and their environment and food. Environ Pollut 131:373-380. doi:10.1016/j.envpol. 2004.03.009

Dauwe T, Jaspers V, Covaci A et al (2005) Feathers as a nondestructive biomonitor for persistent organic pollutants. Environ Toxicol Chem 24:442-449

deGraw WA, Kern MD, King JR (1979) Seasonal changes in the blood composition of captive and free-living White-crowned Sparrows. J Comp Physiol B 129:151-162. doi:10.1007/ BF00798180

Dell'Omo G, Costantini D, Wright J et al (2008) PCBs in the eggs of eurasian kestrels indicate exposure to local pollution. Ambio 37:452-456. doi:10.1579/0044-7447(2008)37

Denneman WD, Douben PET (1993) Trace metals in primary feathers of the Barn Owl (Tyto alba guttatus) in The Netherlands. Environ Pollut 82:301-310. doi:10.1016/0269-7491(93)90133-9

Derlink M, Wernham C, Kovács A, Saurola P, Bertoncelj I, Vrezec A et al. In preparation. A review of raptor monitoring activity across Europe and its implications for capacity building towards pan-European monitoring

DesGranges Rodrigue, Tardif Laperle (1998) Mercury accumulation and biomagnification in ospreys (Pandion haliaetus) in the James Bay and Hudson Bay Regions of Québec. Arch Environ Contam Toxicol 35:330-341

deSilva PE (1981) Determination of lead in plasma and studies on its relationship to lead in erythrocytes. Br J Ind Med 38:209-217

Durant JM, Massemin S, Thouzeau C, Handrich Y (2000) Body reserves and nutritional needs during laying preparation in barn owls. J Comp Physiol B, Biochem Syst Environ Physiol 170:253-260

Duzguner V, Erdogan S (2012) Chronic exposure to imidacloprid induces inflammation and oxidative stress in the liver \& central nervous system of rats. Pestic Biochem Physiol 104:58-64. doi:10.1016/j.pestbp.2012.06.011

Eadsforth CV, Gray A, Harrison EG (1996) Monitoring the exposure of barn owls to second-generation rodenticides in Southern Eire. Pestic Sci 47:225-233. doi:10.1002/(SICI)1096-9063(199607)47: $3<225$ :AID-PS407>3.0.CO;2-P 
Eagles-Smith CA, Ackerman JT, Adelsbach TL et al (2008) Mercury correlations among six tissues for four waterbird species breeding in San Francisco Bay, California, USA. Environ Toxicol Chem 27:2136-2153. doi:10.1897/08-038.1

Ehresman DJ, Froehlich JW, Olsen GW et al (2007) Comparison of human whole blood, plasma, and serum matrices for the determination of perfluorooctanesulfonate (PFOS), perfluorooctanoate (PFOA), and other fluorochemicals. Environ Res 103:176-184. doi:10.1016/j.envres.2006.06.008

Ek KH, Morrison GM, Lindberg P, Rauch S (2004) Comparative tissue distribution of metals in birds in Sweden using ICP-MS and laser ablation ICP-MS. Arch Environ Contam Toxicol 47:259-269. doi:10.1007/s00244-004-3138-6

El-Gendy KS, Aly NM, Mahmoud FH et al (2010) The role of vitamin $\mathrm{C}$ as antioxidant in protection of oxidative stress induced by imidacloprid. Food Chem Toxicol 48:215-221. doi:10.1016/j.fct. 2009.10.003

Elliott JE, Bishop CA (2011) Cyclodiene and other organochlorine pesticides in birds. In: Beyer WN, Meador JP (eds) Environmental contaminants in biota: interpreting tissue concentrations. CRC Press, Taylor \& Francis, Boca Raton, pp 447-477

Elliott JE, Norstrom RJ (1998) Chlorinated hydrocarbon contaminants and productivity of bald eagles on the Pacific coast of Canada. Environ Toxicol Chem 17:1142-1153

Elliott JE, Langelier KE, Mineau P et al (1996) Poisoning of bald eagles and red-tailed hawks by carbofuran and fensulfothion in the lower Fraser valley of British Columbia, Canada. J Wildl Dis 32:486-491

Elliott JE, Wilson LK, Langelier KE et al (1997) Poisoning of birds of prey by the organophosphorus insecticide, phorate. Ecotoxicology 6:219-231

Elliott JE, Moul IE, Cheng KM (1998) Variable reproductive success of bald eagles on the British Columbia coast. J Wildl Manage 62:518-529

Elliott KH, Cesh LS, Dooley JA et al (2009) PCBs and DDE, but not PBDEs, increase with trophic level and marine input in nestling bald eagles. Sci Total Environ 407(12):3867-3875

Elliott JE, Elliott KH, Brogan J et al (2015) Trophic level and carbon source partly explain accumulation of PBDEs and other POPs in urban raptors. Sci Tot Environ 524:157-165. doi:10.1016/j. scitotenv.2015.04.008

Espín S, Martínez-López E, Gómez-Ramírez P et al (2010a) Assessment of organochlorine pesticide exposure in a wintering population of razorbills (Alca torda) from the southwestern Mediterranean. Chemosphere 80:1190-1198. doi:10.1016/j.che mosphere.2010.06.015

Espín S, Martínez López E, María Mojica P, García Fernández AJ (2010b) Development of an analytical method for extracting organochlorine pesticides from feathers. An Vet Murcia 26:77-90. doi:10.6018/analesvet.26.125071

Espín S, Martínez-López E, Gómez-Ramírez P et al (2012a) Razorbills (Alca torda) as bioindicators of mercury pollution in the southwestern Mediterranean. Mar Pollut Bull 64(11):2461-2470

Espín S, Martínez-López E, María-Mojica P, García-Fernández AJ (2012b) Razorbill (Alca torda) feathers as an alternative tool for evaluating exposure to organochlorine pesticides. Ecotoxicology 21:183-190. doi:10.1007/s10646-011-0777-z

Espín S, García-Fernández AJ, Herzke D et al (2014a) Sampling and contaminant monitoring protocol for raptors. Research Networking Programme-EURAPMON, Research and monitoring for and with raptors in Europe. Available on www.eurapmon.net

Espín S, Martínez-López E, Jiménez P et al (2014b) Effects of heavy metals on biomarkers for oxidative stress in Griffon Vulture (Gyps fulvus). Environ Res 129:59-68
Espín S, Martínez-López E, León-Ortega M et al (2014c) Factors that influence mercury concentrations in nestling Eagle Owls (Bubo bubo). Sci Total Environ 470-471:1132-1139

Espín S, Martínez-López E, León-Ortega M et al (2014d) Oxidative stress biomarkers in Eurasian Eagle owls (Bubo bubo) in three different scenarios of heavy metal exposure. Environ Res 131:134-144

Espín S, Martínez-López E, Jiménez P et al (2015) Delta-aminolevulinic acid dehydratase ( $\delta$ ALAD) activity in four free-living bird species exposed to different levels of lead under natural conditions. Environ Res 137C:185-198. doi:10.1016/j.envres. 2014.12.017

Eulaers I, Covaci A, Herzke D et al (2011a) A first evaluation of the usefulness of feathers of nestling predatory birds for nondestructive biomonitoring of persistent organic pollutants. Environ Int 37:622-630. doi:10.1016/j.envint.2010.12.007

Eulaers I, Covaci A, Hofman J et al (2011b) A comparison of nondestructive sampling strategies to assess the exposure of whitetailed eagle nestlings (Haliaeetus albicilla) to persistent organic pollutants. Sci Total Environ 410-411:258-265. doi:10.1016/j. scitotenv.2011.09.070

Eulaers I, Jaspers VLB, Bustnes JO et al (2013) Ecological and spatial factors drive intra- and interspecific variation in exposure of subarctic predatory bird nestlings to persistent organic pollutants. Environ Int 57-58:25-33. doi:10.1016/j.envint.2013.03.009

Eulaers I, Jaspers VLB, Halley DJ et al (2014a) Brominated and phosphorus flame retardants in White-tailed Eagle Haliaeetus albicilla nestlings: bioaccumulation and associations with dietary proxies $\left(\delta^{13} \mathrm{C}, \delta^{15} \mathrm{~N}\right.$ and $\left.\delta^{34} \mathrm{~S}\right)$. Sci Total Environ 478:48-57. doi:10.1016/j.scitotenv.2014.01.051

Eulaers I, Jaspers VLB, Pinxten R et al (2014b) Legacy and currentuse brominated flame retardants in the Barn Owl. Sci Total Environ 472:454-462. doi:10.1016/j.scitotenv.2013.11.054

Evers DC, Burgess NM, Champoux L et al (2005) Patterns and interpretation of mercury exposure in freshwater avian communities in northeastern north America. Ecotoxicology 14:193-221

Faxneld S, Helander B, Bäcklin B-M et al (2014) Biological effects and environmental contaminants in herring and Baltic Sea top predators. Report No. 6, Swedish Museum of Natural History

Ferner RE (2008) Post-mortem clinical pharmacology. Br J Clin Pharmacol 66:430-443. doi:10.1111/j.1365-2125.2008.03231.x

Finkelstein ME, Doak DF, George D et al (2012) Lead poisoning and the deceptive recovery of the critically endangered California condor. Proc Natl Acad Sci USA 109:11449-11454. doi:10. 1073/pnas.1203141109

Fisher PM (2009) Residual concentrations and persistence of the anticoagulant rodenticides brodifacoum and diphacinone in fauna. Doctoral thesis, Lincoln University

Fournier F, Karasov WH, Kenow KP et al (2002) The oral bioavailability and toxicokinetics of methylmercury in common loon (Gavia immer) chicks. Comp Biochem Physiol, Part A Mol Integr Physiol 133:703-714

Franson JC, Pain DJ (2011) Lead in birds. In: Beyer WN, Meador JP (eds) Environmental contaminants in biota: interpreting tissue concentrations. CRC Press, Taylor \& Francis, Boca Raton, Florida, pp 563-593

Frederick P, Jayasena N (2010) Altered pairing behaviour and reproductive success in white ibises exposed to environmentally relevant concentrations of methylmercury. Proc R Soc B rspb20102189. doi:10.1098/rspb.2010.2189

Furness RW (1993) Birds as monitors of pollutants. In: Furness RW, Greenwood JJD (eds) Birds as monitors of environmental change. Chapman and Hall, London, pp 86-143

Furness RW (1996) Cadmium in birds. In: Beyer WN, Heinz GH, Redmon-Norwood AW (eds) Environmental contaminants in 
wildlife: interpreting tissue concentrations. CRC Press, Boca Raton, pp 389-404

Furness RW, Camphuysen KCJ (1997) Seabirds as monitors of the marine environment. ICES J Mar Sci 54:726-737

Furness RW, Muirhead SJ, Woodburn M (1986) Using bird feathers to measure mercury in the environment: relationships between mercury content and moult. Mar Pollut Bull 17:27-30. doi:10. 1016/0025-326X(86)90801-5

Galligan TH, Amano T, Prakash VM et al (2014) Have population declines in Egyptian vulture and red-headed vulture in India slowed since the 2006 ban on veterinary diclofenac? Bird Conserv Int 24:272-281. doi:10.1017/S0959270913000580

Gangoso L, Alvarez-Lloret P, Rodríguez-Navarro AAB et al (2009) Long-term effects of lead poisoning on bone mineralization in vultures exposed to ammunition sources. Environ Pollut 157:569-574. doi:10.1016/j.envpol.2008.09.015

García-Fernández AJ (2014) Ecotoxicology, avian. Encyclopedia of toxicology, 3rd edn, vol 2, pp 289-294

García-Fernández AJ, Sánchez-García JA, Jiménez-Montalban P, Luna A (1995) Lead and cadmium in wild birds in southeastern Spain. Environ Toxicol Chem 14:2049-2058. doi:10.1002/etc. 5620141207

García-Fernández AJ, Sánchez-García JA, Gómez-Zapata M, Luna A (1996) Distribution of cadmium in blood and tissues of wild birds. Arch Environ Contam Toxicol 30:252-258. doi:10.1007/ BF00215805

García-Fernández AJ, Motas-Guzmán M, Navas I et al (1997) Environmental exposure and distribution of lead in four species of raptors in Southeastern Spain. Arch Environ Contam Toxicol 33:76-82

García-Fernández AJ, Martinez-Lopez E, Romero D et al (2005a) High levels of blood lead in griffon vultures (Gyps fulvus) from Cazorla Natural Park (southern Spain). Environ Toxicol 20:459-463. doi:10.1002/tox.20132

García-Fernández AJ, Romero D, Martínez-López E et al (2005b) Environmental lead exposure in the European Kestrel (Falco tinnunculus) from Southeastern Spain: the influence of leaded gasoline regulations. Bull Environ Contam Toxicol 74:314-319. doi:10.1007/s00128-004-0586-7

García-Fernández AJ, Calvo JF, Martínez-López E et al (2008) Raptor ecotoxicology in Spain: a review on persistent environmental contaminants. Ambio 37:432-439

García-Fernández AJ, Espín S, Martínez-López E (2013a) Feathers as a biomonitoring tool of polyhalogenated compounds: a review. Environ Sci Technol 47(7):3028-3043

García-Fernández AJ, María-Mojica P, Grau LV et al (2013b) Residuos de antibióticos de uso veterinario en plasma sanguíneo de una población de buitre leonado (Gyps fulvus). XX Congreso Español de Toxicología y IV Iberoamericano, Salamanca, España

Gibbons D, Morrissey C, Mineau P (2014) A review of the direct and indirect effects of neonicotinoids and fipronil on vertebrate wildlife. Environ Sci Pollut Res 22:103-118. doi:10.1007/ s11356-014-3180-5

Glaser LC (1999) Organophosphorus and carbamate pesticides (Chap. 39). In: Field manual of wildlife disease-general field procedures and diseases of birds, pp 287-294

Golden NH, Rattner BA, Cohen JB et al (2003) Lead accumulation in feathers of nestling black-crowned night herons (Nycticorax nycticorax) experimentally treated in the field. Environ Toxicol Chem 22:1517-1524

Gómez-Ramírez P, Shore RF, van den Brink NW et al (2014) An overview of existing raptor contaminant monitoring activities in Europe. Environ Int 67:12-21

Goymann W, Jenni-Eiermann S (2005) Introduction to the European Science Foundation Technical Meeting: analysis of Hormones in droppings and egg yolk of birds. Ann N Y Acad Sci 1046:1-4. doi:10.1196/annals.1343.002
Gray A, Eadsforth CV, Dutton AJ, Vaughan JA (1992) Toxicity of second generation rodenticides to barn owls. Proceedings Brighton Crop Protection Conference, Pests and Diseases, November 23-26. British Crop Protection Council, Farnham, pp 781-786

Gray A, Eadsforth CV, Dutton AJ, Vaughan JA (1994) Non-invasive method for monitoring the exposure of Barn owls to secondgeneration rodenticides. Pestic Sci 41:339-343. doi:10.1002/ps. 2780410409

Green RE, Newton I, Shultz S et al (2004) Diclofenac poisoning as a cause of vulture population declines across the Indian subcontinent. J Appl Ecol 41:793-800. doi:10.1111/j.0021-8901.2004.00954.x

Green RE, Taggart MA, Das D et al (2006) Collapse of Asian vulture populations: risk of mortality from residues of the veterinary drug diclofenac in carcasses of treated cattle. J Appl Ecol 43:949-956. doi:10.1111/j.1365-2664.2006.01225.x

Green RE, Taggart MA, Senacha KR et al (2007) Rate of decline of the oriental white-backed vulture population in India estimated from a survey of diclofenac residues in carcasses of ungulates. PLoS ONE. doi:10.1371/journal.pone.0000686

Greichus YA, Greichus A (1974) Dieldrin-14C residues on feathers of birds with surgically removed uropygial glands. Bull Environ Contam Toxicol 12:413-416

Group of Scientists (2014) Wildlife and human health risks from lead-based ammunition in Europe: a consensus statement by scientists. Available from: http://www.zoo.cam.ac.uk/leadam muntionstatement/

Guigueno MF, Elliott KH, Wayland M et al (2012) Differential exposure of alpine ospreys to mercury: melting glaciers, hydrology or deposition patterns? Environ Int 40:24-32

Guitart R, Sachana M, Caloni F et al (2010) Animal poisoning in Europe. Part 3: wildlife. Vet J 183:260-265. doi:10.1016/j.tvj1. 2009.03.033

Hahn E, Hahn K, Stoeppler M (1993) Bird feathers as bioindicators in areas of the German Environmental Specimen Bank-bioaccumulation of mercury in food chains and exogenous deposition of atmospheric pollution with lead and cadmium. Sci Total Environ 139-140:259-270

Häkkinen I, Häsänen E (1980) Mercury in eggs and nestlings of the osprey (Pandion haliaetus) in Finland and its bioaccumulation from fish. Ann Zool Fenn 17:131-139

Hallmann CA, Foppen RPB, van Turnhout CAM et al (2014) Declines in insectivorous birds are associated with high neonicotinoid concentrations. Nature 511:341-343. doi:10.1038/ nature 13531

Hamilton GA, Stanley PI (1975) Further cases of poisoning of wild geese by an organophosphorus winter wheat seed treatment. Wildfowl 26:49-54

Hardey J, Clark H, Wernham C et al (2006) Raptors: A Field Guide to Surveying and Monitoring, 2nd edn. Stationery Office Books, Edinburgh

Harris ML, Elliott JE (2011) Effects of polychlorinated biphenyls, dibenzo-p-dioxins and dibenzofurans, and polybrominated diphenyls ethers in wildbirds. In: Beyer WN, Meador JP (eds) Environmental contaminants in biota: interpreting tissue concentrations. CRC Press, Taylor \& Francis, Boca Raton, pp 477-531

Hatcher-Martin JM, Gearing M, Steenland K et al (2012) Association between polychlorinated biphenyls and Parkinson's disease neuropathology. Neurotoxicology 33:1298-1304. doi:10.1016/j. neuro.2012.08.002

Heinz G (1974) Effects of low dietary levels of methyl mercury on mallard reproduction. Bull Environ Contam Toxicol 11:386-392. doi:10.1007/BF01684947

Heinz GH, Hoffman DJ (2003) Embryotoxic thresholds of mercury: estimates from individual mallard eggs. Arch Environ Contam Toxicol 44:0257-0264. doi:10.1007/s00244-002-2021-6 
Hela DG, Konstantinou IK, Sakellarides TM et al (2006) Persistent organochlorine contaminants in liver and fat of birds of prey from Greece. Arch Environ Contam Toxicol 50:603-613. doi:10. 1007/s00244-005-0101-0

Helander B (2003) The white-tailed sea eagle in Sweden-reproduction, numbers and trends. In: Helander $B$, Marquiss $M$, Bowerman W (eds) SEA EAGLE 2000. Swedish Society for Nature Conservation/SNF \& Åtta.45 Tryckeri AB, Stockholm, pp 57-66

Helander B, Olsson M, Reutergårdh L (1982) Residue levels of organochlorine and mercury compounds in unhatched eggs and the relationships to breeding success in white-tailed sea eagles Haliaeetus albicilla in Sweden. Holarctic Ecology 5:349-366. doi: $10.2307 / 3682220$

Helander B, Olsson A, Bignert A et al (2002) The role of DDE, PCB, coplanar PCB and eggshell parameters for reproduction in the white-tailed sea eagle (Haliaeetus albicilla) in Sweden. Ambio 31:386-403

Helander B, Axelsson J, Borg H et al (2009) Ingestion of lead from ammunition and lead concentrations in white-tailed sea eagles (Haliaeetus albicilla) in Sweden. Sci Total Environ 407:55555563. doi:10.1016/j.scitotenv.2009.07.027

Helgason LB, Verreault J, Braune BM et al (2010) Relationship between persistent halogenated organic contaminants and TCDD-toxic equivalents on EROD activity and retinoid and thyroid hormone status in northern fulmars. Sci Total Environ 408:6117-6123. doi:10.1016/j.scitotenv.2010.08.037

Henny CJ, Blus LJ (1986) Radiotelemetry locates wintering grounds of DDE-contaminated black-crowned night-herons. Report, United States Geological Survey, pp 236-241

Henny CH, Elliott JE (2007) Toxicology. In: Bird DM, Bildstein KL (eds) Raptor Research and Management Techniques, Hancock House Publishers LTD. U.S.A, Washington, pp 329-350

Henny CJ, Meeker DL (1981) An evaluation of blood plasma for monitoring DDE in birds of prey. Environ Pollut (Series A) 25:291-304

Henny CJ, Blus LJ, Kolbe EJ, Fitzner RE (1985) Organophosphate insecticide (famphur) topically applied to cattle kills magpies and hawks. J Wildl Manag 49:648-658. doi:10.2307/3801689

Henny CJ, Hill EF, Hoffman DJ et al (2002) Nineteenth century mercury: hazard to wading birds and cormorants of the Carson River, Nevada. Ecotoxicology 11:213-231

Henny CJ, Kaiser JL, Grove RA et al (2009) Polybrominated diphenyl ether flame retardants in eggs may reduce reproductive success of ospreys in Oregon and Washington, USA. Ecotoxicology 18:802-813. doi:10.1007/s10646-009-0323-4

Henriksen EO, Gabrielsen GW, Skaare JU (1996) Levels and congener pattern of polychlorinated biphenyls in kittiwakes (Rissa tridactyla), in relation to mobilization of body-lipids associated with reproduction. Environ Pollut 92:27-37

Henriksen EO, Gabrielsen GW, Skaare JU (1998) Validation of the use of blood samples to assess tissue concentrations of organochlorines in glaucous gulls, Larus hyperboreus. Chemosphere 37:2627-2643. doi:10.1016/S0045-6535(98)00162-3

Herzke D, Kallenborn R, Nygård T (2002) Organochlorines in egg samples from Norwegian birds of prey: congener-, isomer- and enantiomer specific considerations. Sci Total Environ 291:59-71. doi:10.1016/S0048-9697(01)01092-0

Herzke D, Berger U, Kallenborn R et al (2005) Brominated flame retardants and other organobromines in Norwegian predatory bird eggs. Chemosphere 61:441-449. doi:10.1016/j.chemosp here.2005.01.066

Herzke D, Jaspers V, Boertmann D et al (2011) PFCs in feathers of white-tailed eagles (Haliaeetus albicilla) from Greenland and Norway, useful for nondestructive sampling? Organohalogen Compd 73:1337e1339
Hickey JJ (1969) Peregrine falcon populations: their biology and decline. University of Wisconsin Press

Hill EF (2003) Wildlife toxicology of organophosphorus and carbamate pesticides (Chap. 12). In: Hoffman DJ, Rattner BA, Burton GA (eds) Handbook of ecotoxicology, 2nd edn. J. Cairns. Lewis, CRC Press, Boca Raton

Hill EF, Shaffner CS (1976) Sexual maturation and productivity of Japanese quail fed graded concentrations of mercuric chloride. Poult Sci 55:1449-1459

Hobson KA (2011) Isotopic ornithology: a perspective. J Ornithol 152:49-66. doi:10.1007/s10336-011-0653-x

Hochleithner M (1994) Chapter 11 biochemistries. In: Ritchie BW, Harrison GJ, Harrision LR (eds) Avian medicine: principles and application. Wingers Publishing, Florida

Hoffman DJ, Moore JM (1979) Teratogenic effects of external egg applications of methyl mercury in the mallard, Anas platyrhynchos. Teratology 20:453-461. doi:10.1002/tera.1420200315

Hogstad O, Nygård T, Gätzschmann P et al (2003) Bird skins in museum collections: are they suitable as indicators of environmental metal load after conservation procedures? Environ Monit Assess 87:47-56

Holt G, Frøslie A, Norheim G (1979) Mercury, DDE, and PCB in the avian fauna in Norway 1965-1976. Acta Vet Scand Suppl 3-28

Hopkins WA, Hopkins LB, Unrine JM et al (2007) Mercury concentrations in tissues of osprey from the Carolinas, USA. J Wildl Manag 71:1819-1829. doi:10.2193/2006-016

Howald GR (1997) The risk of non-target species poisoning from brodifacoum used to eradicate rats from Langara Island, British Columbia. Masters thesis, Department of Animal Science, University of British Columbia

Hoyt DF (1979) Practical methods of estimating volume and fresh weight of bird eggs. Auk 96:73-77

Huckle KR, Hutson DH, Warburton PA (1988) Elimination and accumulation of the rodenticide flocoumafen in rats following repeated oral administration. Xenobiotica 18:1465-1479. doi:10. 3109/00498258809042269

Huckle KR, Warburton PA, Forbes S, Logan CJ (1989) Studies on the fate of flocoumafen in the Japanese quail (Coturnix coturnix japonica). Xenobiotica 19:51-62. doi:10.3109/00498258909034676

Hunt WG, Burnham W, Parish CN et al (2006) Bullet fragments in deer remains: implications for lead exposure in avian scavengers. Wildl Soc Bull 34:167-170. doi:10.2193/0091-7648(2006)

Jain T, Koley KM, Vadlamudi VP et al (2009) Diclofenac-induced biochemical and histopathological changes in white leghorn birds (Gallus domesticus). Indian J Pharmacol 41:237-241. doi:10.4103/0253-7613.58515

Jaspers V, Dauwe T, Pinxten R et al (2004) The importance of exogenous contamination on heavy metal levels in bird feathers. A field experiment with free-living great tits, Parus major. J Environ Monit 6:356-360. doi:10.1039/b314919f

Jaspers VLB, Covaci A, Maervoet J et al (2005) Brominated flame retardants and organochlorine pollutants in eggs of little owls (Athene noctua) from Belgium. Environ Poll 136(1):81-88

Jaspers VLB, Voorspoels S, Covaci A, Eens M (2006) Can predatory bird feathers be used as a non-destructive biomonitoring tool of organic pollutants? Biol Lett 2:283-285. doi:10.1098/rsbl.2006. 0450

Jaspers VLB, Covaci A, Van den Steen E, Eens M (2007a) Is external contamination with organic pollutants important for concentrations measured in bird feathers? Environ Int 33:766-772. doi:10. 1016/j.envint.2007.02.013

Jaspers VLB, Voorspoels S, Covaci A et al (2007b) Evaluation of the usefulness of bird feathers as a non-destructive biomonitoring tool for organic pollutants: a comparative and meta-analytical approach. Environ Int 33:328-337. doi:10.1016/j.envint.2006. 11.011 
Jaspers VLB, Covaci A, Deleu P et al (2008) Preen oil as the main source of external contamination with organic pollutants onto feathers of the common magpie (Pica pica). Environ Int 34:741-748. doi:10.1016/j.envint.2007.12.002

Jaspers VLB, Rodriguez FS, Boertmann D et al (2011) Body feathers as a potential new biomonitoring tool in raptors: a study on organohalogenated contaminants in different feather types and preen oil of West Greenland white-tailed eagles (Haliaeetus albicilla). Environ Int 37:1349-1356. doi:10.1016/j.envint.2011.06.004

Jaspers VLB, Herzke D, Eulaers I et al (2013a) Perfluoroalkyl substances in soft tissues and tail feathers of Belgian barn owls (Tyto alba) using statistical methods for left-censored data to handle non-detects. Environ Int 52:9-16

Jaspers VLB, Sonne C, Soler-Rodriguez F et al (2013b) Persistent organic pollutants and methoxylated polybrominated diphenyl ethers in different tissues of white-tailed eagles (Haliaeetus albicilla) from West Greenland. Environ Pollut 175:137-146. doi:10.1016/j.envpol.2012.12.023

Jones PD, Hu W, De Coen W et al (2003) Binding of perfluorinated fatty acids to serum proteins. Environ Toxicol Chem 22:2639-2649

Kalisinska E, Gorecki J, Lanocha N et al (2014) Total and methylmercury in soft tissues of white-tailed eagle (Haliaeetus albicilla) and Osprey (Pandion haliaetus) collected in Poland. Ambio 43:858-870. doi:10.1007/s13280-014-0533-8

Kawai S, Fukushima M, Miyazaki N, Tatsukawa R (1988) Relationship between lipid composition and organochlorine levels in the tissues of striped dolphin. Mar Pollut Bull 19:129-133. doi:10. 1016/0025-326X(88)90709-6

Kenntner N, Krone O, Altenkamp R, Tataruch F (2003a) Environmental contaminants in liver and kidney of free-ranging northern goshawks (Accipiter gentilis) from three regions of Germany. Arch Environ Contam Toxicol 45:128-135. doi:10.1007/s00244002-2100-8

Kenntner N, Krone O, Oehme G et al (2003b) Organochlorine contaminants in body tissue of free-ranging white-tailed eagles from northern regions of Germany. Environ Toxicol Chem 22:1457-1464

Kolpin DW, Furlong ET, Meyer MT et al (2002) Pharmaceuticals, hormones, and other organic wastewater contaminants in U.S. streams, 1999-2000: a national reconnaissance. Environ Sci Technol 36:1202-1211

Krone O, Wille F, Kenntner $\mathrm{N}$ et al (2004) Mortality factors, environmental contaminants, and parasites of white-tailed sea eagles from Greenland. Avian Dis 48:417-424

Krone O, Stjernberg T, Kenntner N et al (2006) Mortality factors, helminth burden, and contaminant residues in white-tailed sea eagles (Haliaeetus albicilla) from Finland. Ambio 35:98-104

Krone O, Kenntner N, Trinogga A et al (2009) Lead poisoning in Whitetailed Sea Eagles: Causes and approaches to solutions in Germany. In: Watson RT, Fuller M, Pokras M, Hunt WG (eds) Ingestion of Lead from Spent Ammunition: Implications for Wildlife and Humans. The Peregrine Fund, Boise, Idaho, USA., pp 289-301

Langlier KM (1993) Barbiturate poisoning in twenty-nine bald eagles. In: Redig PT et al (eds) Raptor biomedicine. University of Minnesota Press, Minneapolis, pp 231-232

Larsson P, Lindegren A (1987) Animals need not be killed to reveal their body-burdens of chlorinated hydrocarbons. Environ Pollut 45:73-78. doi:10.1016/0269-7491(87)90017-0

Lazarus RS, Rattner BA, Brooks BW et al (2015) Exposure and food web transfer of pharmaceuticals in ospreys (Pandion haliaetus): predictive model and empirical data. Integr Environ Assess Manag 11:118-129. doi:10.1002/ieam.1570

Lees P, Landoni MF, Giraudel J, Toutain PL (2004) Pharmacodynamics and pharmacokinetics of nonsteroidal anti-inflammatory drugs in species of veterinary interest. J Vet Pharmacol Ther 27:479-490. doi:10.1111/j.1365-2885.2004.00617.x
Leslie HA, Thomsen C, Brandsma S et al (2013) Decabromodiphenylether in human whole blood and serum. Sixth International Symposium On Flame Retardants, San Francisco

Lewis SA, Furness RW (1991) Mercury accumulation and excretion in laboratory reared black-headed gull Larus ridibundus chicks. Arch Environ Contam Toxicol 21:316-320. doi:10.1007/BF01055352

Lewis SA, Becker PH, Furness RW (1993) Mercury levels in eggs, tissues, and feathers of herring gulls Larus argentatus from the German Wadden Sea Coast. Environ Pollut 80:293-299. doi:10. 1016/0269-7491(93)90051-O

Lindberg P, Odsjö T (1983) Mercury levels in feathers of peregrine falcon Falco peregrinus compared with total mercury content in some of its prey species in Sweden. Environ Pollut Ser B, Chem Phys 5:297-318. doi:10.1016/0143-148X(83)90023-X

Lindberg P, Sellström U, Häggberg L, de Wit CA (2004) Higher brominated diphenyl ethers and hexabromocyclododecane found in eggs of peregrine falcons (Falco peregrinus) breeding in Sweden. Environ Sci Technol 38:93-96

Lopes I, Sedlmayr A, Moreira-Santos M et al (2010) European beeeater (Merops apiaster) populations under arsenic and metal stress: evaluation of exposure at a mining site. Environ Monit Assess 161:237-245. doi:10.1007/s10661-008-0741-4

Lopez-Antia A, Ortiz-Santaliestra ME, Mougeot F, Mateo R (2013) Experimental exposure of red-legged partridges (Alectoris rufa) to seeds coated with imidacloprid, thiram and difenoconazole. Ecotoxicology 22:125-138. doi:10.1007/s10646-012-1009-x

Lopez-Antia A, Ortiz-Santaliestra ME, Mougeot F, Mateo R (2015) Imidacloprid-treated seed ingestion has lethal effect on adult partridges and reduces both breeding investment and offspring immunity. Environ Res 136:97-107. doi:10.1016/j.envres.2014. 10.023

Love RA, Webon C, Glue DE et al (2000) Changes in the food of British Barn Owls (Tyto alba) between 1974 and 1997. Mammal Rev 30:107-129. doi:10.1046/j.1365-2907.2000.00060.x

Lundholm CD (1997) DDE-induced eggshell thinning in birds: effects of $\mathrm{p}, \mathrm{p}^{\prime}$-DDE on the calcium and prostaglandin metabolism of the eggshell gland. Comp Biochem Physiol C: Pharmacol Toxicol Endocrinol 118:113-128

Lundholm CE, Mathson K (1986) Effect of some metal compounds on the $\mathrm{Ca}^{2+}$ binding and $\mathrm{Ca}^{2+}-\mathrm{Mg}^{2+}$-ATPase activity of eggshell gland mucosa homogenate from the domestic fowl. Acta Pharmacol Toxicol (Copenh) 59:410-415

Lutz PM, Wilson TJ, Ireland J et al (1999) Elevated immunoglobulin $\mathrm{E}$ (IgE) levels in children with exposure to environmental lead. Toxicology 134:63-78

Luzardo OP, Ruiz-Suárez N, Henríquez-Hernández LA et al (2014) Assessment of the exposure to organochlorine pesticides, PCBs and PAHs in six species of predatory birds of the Canary Islands, Spain. Sci Total Environ 472:146-153. doi:10.1016/j.scitotenv. 2013.11.021

Maceda-Veiga A, Figuerola J, Martínez-Silvestre A et al (2015) Inside the Redbox: applications of haematology in wildlife monitoring and ecosystem health assessment. Sci Total Environ 514:322-332. doi:10.1016/j.scitotenv.2015.02.004

Maervoet J, Beck V, Roelens SA et al (2005) Uptake and tissuespecific distribution of selected polychlorinated biphenyls in developing chicken embryos. Environ Toxicol Chem 24:597602. doi:10.1897/04-266R.1

Mañosa S, Mateo R, Freixa C, Guitart R (2003) Persistent organochlorine contaminants in eggs of northern goshawk and Eurasian buzzard from northeastern Spain: temporal trends related to changes in the diet. Environ Pollut 122:351-359

María-Mojica P, Jiménez P, Barba A et al (2000) Residues of organochlorine insecticides in European kestrels (Falco tinnunculus) from Murcia Region. An Vet Murcia 16:55-66 
Martinez-Haro M, Green AJ, Mateo R (2011a) Effects of lead exposure on oxidative stress biomarkers and plasma biochemistry in waterbirds in the field. Environ Res 111:530-538. doi:10. 1016/j.envres.2011.02.012

Martinez-Haro M, Taggart MA, Martín-Doimeadiøs RRC et al (2011b) Identifying sources of $\mathrm{Pb}$ exposure in waterbirds and effects on porphyrin metabolism using noninvasive fecal sampling. Environ Sci Technol 45:6153-6159. doi:10.1021/es2009242

Martínez-Haro M, Viñuela J, Mateo R (2007) Exposure of birds to cholinesterase-inhibiting pesticides following a forest application for tick control. Environ Toxicol Pharmacol 23:347-349. doi:10.1016/j.etap.2006.11.011

Martinez-Lopez E, Maria-Mojica P, Martinez JE et al (2007) Organochlorine residues in booted eagle (Hieraaetus pennatus) and goshawk (Accipiter gentilis) eggs from southeastern Spain. Environ Toxicol Chem 26(11):2373-2378

Martínez-López E, María-Mójica P, Martínez JE et al (2002) Pluma de Águila calzada (Hieraaetus pennatus) como unidad biomonitora de la exposición ambiental a cadmio y plomo. Anales de Veterinaria 18:69-74. doi:10.6018/analesvet.18.16741

Martínez-López E, Martínez JE, María-Mojica P et al (2004) Lead in feathers and delta-aminolevulinic acid dehydratase activity in three raptor species from an unpolluted Mediterranean forest (Southeastern Spain). Arch Environ Contam Toxicol 47:270-275. doi:10.1007/s00244-004-3027-z

Martínez-López E, María-Mojica P, Martínez JE et al (2005) Cadmium in feathers of adults and blood of nestlings of three raptor species from a nonpolluted mediterranean forest, Southeastern Spain. Bull Environ Contam Toxicol 74:477-484. doi:10.1007/s00128-005-0610-6

Martínez-López E, Romero D, María Mojica P et al (2006) Detection of strychnine by gas chromatography-mass spectrometry in the carcass of a Bonelli's eagle (Hieraaetus fasciatus). Veterinary Record 159:182-183

Martínez-López E, Romero D, María-Mojica P et al (2009) Changes in blood pesticide levels in booted eagle (Hieraaetus pennatus) associated with agricultural land practices. Ecotoxicol Environ Saf 72:45-50. doi:10.1016/j.ecoenv.2008.02.012

Mateo R (2009) Lead poisoning in wild birds in Europe and the regulations adopted in different countries. In: Watson RT, Fuller M, Pokras M, Hunt WG (eds) Ingestion of Lead from Spent Ammunition: Implications for Wildlife and Humans. The Peregrine Fund, Boise, Idaho, USA

Mateo R, Estrada J, Paquet J-Y et al (1999) Lead shot ingestion by marsh harriers Circus aeruginosus from the Ebro delta, Spain. Environ Pollut 104:435-440. doi:10.1016/S0269-7491(98)00169-9

Mateo R, Cadenas R, Máñez M, Guitart R (2001) Lead shot ingestion in two raptor species from Doñana, Spain. Ecotoxicol Environ Saf 48:6-10. doi:10.1006/eesa.2000.1996

Mateo RW, Beyer WN, Spann JW et al (2003) Relationship between oxidative stress, pathology, and behavioral signs of lead poisoning in mallards. J Toxicol Environ Health Part A 66:1371-1389. doi:10.1080/15287390306390

Mateo R, Taggart MA, Green AJ et al (2006) Altered porphyrin excretion and histopathology of greylag geese (Anser anser) exposed to soil contaminated with lead and arsenic in the Guadalquivir Marshes, southwestern Spain. Environ Toxicol Chem 25:203-212

Mateo R, Sánchez-Barbudo IS, Camarero PR, Martínez JM (2015) Risk assessment of bearded vulture (Gypaetus barbatus) exposure to topical antiparasitics used in livestock within an ecotoxicovigilance framework. Sci Total Environ 536:704-712

Meyer J, Jaspers VLB, Eens M, de Coen W (2009) The relationship between perfluorinated chemical levels in the feathers and livers of birds from different trophic levels. Sci Total Environ 407:5894-5900. doi:10.1016/j.scitotenv.2009.07.032
Mineau P, Palmer C (2013) The impact of the nation's most widely used insecticides on birds. American Bird Conservancy, USA

Mineau P, Fletcher MR, Glaser LC et al (1999) Poisoning of raptors with organophosphorus and carbamate pesticides with emphasis on Canada, U.S. and U.K. J Raptor Res 33:1-37

Misztal-Szkudlińska M, Szefer P, Konieczka P, Namieśnik J (2012) Mercury in different feather types from Great Cormorants (Phalacrocorax carbo L.) inhabiting the Vistula Lagoon ecosystem in Poland. Bull Environ Contam Toxicol 89:841-844. doi:10.1007/s00128-012-0771-z

Mohamed F, Gawarammana I, Robertson TA et al (2009) Acute Human Self-Poisoning with Imidacloprid Compound: a Neonicotinoid Insecticide. PLoS ONE 4:e5127. doi:10.1371/journal. pone. 0005127

Morrissey CA, Bendell-Young LI, Elliott JE (2005) Assessing tracemetal exposure to American dippers in mountain streams of southwestern British Columbia, Canada. Environ Toxicol Chem 24:836-845

Morrissey CA, Elliott JE, Ormerod SJ (2010) Diet shifts during egg laying: implications for measuring contaminants in bird eggs. Environ Pollut 158:447-454. doi:10.1016/j.envpol.2009.08.040

Morrissey CA, Mineau P, Devries JH et al (2015) Neonicotinoid contamination of global surface waters and associated risk to aquatic invertebrates: a review. Environ Int 74:291-303. doi:10. 1016/j.envint.2014.10.024

Mulhern BM, Reichel WL (1971) The effect of putrefaction of eggs upon residue analysis of DDT and metabolites. Bull Environ Contam Toxicol 5:222-225. doi:10.1007/BF01558315

Naidoo V, Wolter K, Cuthbert R, Duncan N (2009) Veterinary diclofenac threatens Africa's endangered vulture species. Regul Toxicol Pharmacol 53:205-208. doi:10.1016/j.yrtph.2009.01.010

Nakata H, Sasaki H, Takemura A et al (2007) Bioaccumulation, temporal trend, and geographical distribution of synthetic musks in the marine environment. Environ Sci Technol 41:2216-2222

Nam D-H, Anan Y, Ikemoto T et al (2005) Specific accumulation of 20 trace elements in great cormorants (Phalacrocorax carbo) from Japan. Environ Pollut 134:503-514. doi:10.1016/j.envpol.2004.09.003

NAS (1978) An assessment of mercury in the environment. National Academy of Sciences, Washington DC

Negro JJ, Donázar JA, Hiraldo F et al (1993) Organochlorine and heavy metal contamination in non-viable eggs and its relation to breeding success in a Spanish population of Lesser Kestrels (Falco naumanni). Environ Pollut 82:201-205

Newton I, Bogan J (1978) The role of different organochlorine compounds in the breeding of British sparrowhawks. J Appl Ecol $15: 105-116$

Newton I, Wyllie I (1992) Recovery of a sparrowhawk population in relation to declining pesticide contamination. J Appl Ecol 29:476-484. doi:10.2307/2404515

Newton I, Wyllie I, Asher A (1993) Long-term trends in organochlorine and mercury residues in some predatory birds in Britain. Environ Pollut 79:143-151

Newton I, Wyllie I, Gray A, Eadsforth CV (1994) The toxicity of the rodenticide flocoumafen to barn owls and its elimination via pellets. Pestic Sci 41:187-193. doi:10.1002/ps.2780410304

Nisbet ICT (1989) Organochlorines, reproductive impairment and declines in Bald eagle Haliaeetus leucocephalus populations: mechanisms and dose-response relationships. In: Meyburg B-U, Chancellor RD (eds) Raptors in the modern world. WWGBP, Berlin, London and Paris

Nisbet ICT, Reynolds LM (1984) Organochlorine residues in common terns and associated estuarine organisms, Massachusetts, USA, 1971-81. Marine Environ Res 11:33-66. doi:10.1016/01411136(84)90009-6

Noble RC, Cocchi M (1990) Lipid metabolism and the neonatal chicken. Prog Lipid Res 29:107-140 
Norheim G, Frøslie A (1978) The degree of methylation and organ distribution of mercury in some birds of prey in Norway. Acta Pharmacol Toxicol (Copenh) 43:196-204

Nygård T (1999) Long term trends in pollutant levels and shell thickness in eggs of Merlin in Norway, in relation to its migration pattern and numbers. Ecotoxicology 8:23-31. doi:10. 1023/A:1008897211711

Nyholm NEI (1998) Influence of heavy metal exposure during different phases of the ontogeny on the development of pied flycatchers, Ficedula hypoleuca, in natural populations. Arch Environ Contam Toxicol 35:632-637. doi:10.1007/s002449900425

Oaks JL, Gilbert M, Virani MZ et al (2004) Diclofenac residues as the cause of vulture population decline in Pakistan. Nature 427:630-633. doi:10.1038/nature02317

Olsson A, Ceder K, Bergman A, Helander B (2000) Nestling blood of the white-tailed sea eagle (Haliaeetus albicilla) as an indicator of territorial exposure to organohalogen compounds-an evaluation. Environ Sci Technol 34:2733-2740. doi:10.1021/es991426k

Orlowski G, Polechonski R, Dobicki W, Zawada Z (2007) Heavy metal concentrations in the tissues of the black-headed gull. Pol J Ecol 55(4):783-793

Ortego J, Jiménez M, Díaz M, Rodríguez RC (2006) Mercury in feathers of nestling eagle owls, Bubo bubo L., and muscle of their main prey species in Toledo Province, Central Spain. Bull Environ Contam Toxicol 76:648-655. doi:10.1007/s00128-0060969-z

Pain D, Burneleau G, Bavoux C, Wyatt C (1999) Levels of polychlorinated biphenlyls, organochlorine pesticides, mercury and lead in relation to shell thickness in marsh harrier (Circus aeruginosus) eggs from Charente-Maritime, France. Environ Pollut 104:61-68. doi:10.1016/S0269-7491(98)00154-7

Pain DJ, Meharg AA, Ferrer M et al (2005) Lead concentrations in bones and feathers of the globally threatened Spanish imperial eagle. Biol Conserv 121:603-610. doi:10.1016/j.biocon.2004.06. 012

Pain DJ, Carter I, Sainsbury AW et al (2007) Lead contamination and associated disease in captive and reintroduced red kites Milvus milvus in England. Sci Total Environ 376:116-127. doi:10.1016/ j.scitotenv.2007.01.062

Pain DJ, Cromie RL, Newth J et al (2010) Potential hazard to human health from exposure to fragments of lead bullets and shot in the tissues of game animals. PLoS ONE 5:e10315. doi:10.1371/ journal.pone.0010315

Pap PL, Vágási CI, Osváth G et al (2010) Seasonality in the uropygial gland size and feather mite abundance in house sparrows Passer domesticus: natural covariation and an experiment. J Avian Biol 41:653-661. doi:10.1111/j.1600-048X.2010.05146.x

Payne-James J, Busuttil A, Smock W (2003) Forensic medicine: clinical and pathological aspects. Cambridge University Press

Peakall DB, Gilman AP (1979) Limitations of expressing organochlorine levels in eggs on a lipid-weight basis. Bull Environ Contam Toxicol 23:287-290. doi:10.1007/BF01769958

Pereira MG, Walker LA, Wright J et al (2009) Concentrations of polycyclic aromatic hydrocarbons (PAHs) in the eggs of predatory birds in Britain. Environ Sci Technol 43:9010-9015. doi:10.1021/es901805e

Pilastro Congiu L, Tallandini L, Turchetto M (1993) The use of bird feathers for the monitoring of cadmium pollution. Arch Environ Contam Toxicol 24:355-358

Podlesak DW, McWilliams SR, Hatch KA (2005) Stable isotopes in breath, blood, feces and feathers can indicate intra-individual changes in the diet of migratory songbirds. Oecologia 142:501-510. doi:10.1007/s00442-004-1737-6

Pounds JG (1984) Effect of lead intoxication on calcium homeostasis and calcium-mediated cell function: a review. Neurotoxicology $5: 295-331$
Presti FT, Meyer J, Antas PTZ et al (2013) Non-invasive genetic sampling for molecular sexing and microsatellite genotyping of hyacinth macaw (Anodorhynchus hyacinthinus). Genet Mol Biol 36:129-133. doi:10.1590/S1415-47572013005000001

Rainio MJ, Kanerva M, Wahlberg N et al (2012) Variation of basal EROD activities in ten passerine bird species-relationships with diet and migration status. PLoS ONE 7:e33926. doi:10. 1371/journal.pone.0033926

Rajaei F, Sari AE, Bahramifar N et al (2011) Persistent organic pollutants in muscle and feather of ten avian species from Māzandarān Province of Iran, on the coast of the Caspian Sea. Bull Environ Contam Toxicol 87:678-683. doi:10.1007/s00128011-0420-y

Ratcliffe DA (1970) Changes attributable to pesticides in egg breakage frequency and eggshell thickness in some British birds. J Appl Ecol 7:67-115. doi:10.2307/2401613

Ratcliffe D (1980) The Peregrine Falcon. Poyser, Calton

Rattner BA (2009) History of wildlife toxicology. Ecotoxicology 18:773-783. doi:10.1007/s10646-009-0354-x

Rattner BA, Horak KE, Warner SE et al (2011) Acute toxicity, histopathology, and coagulopathy in American kestrels (Falco sparverius) following administration of the rodenticide diphacinone. Environ Toxicol Chem 30:1213-1222. doi:10.1002/etc.490

Rattner BA, Horak KE, Lazarus RS et al (2014a) Toxicokinetics and coagulopathy threshold of the rodenticide diphacinone in eastern screech-owls (Megascops asio). Environ Toxicol Chem 33:74-81. doi:10.1002/etc. 2390

Rattner BA, Lazarus RS, Elliott JE et al (2014b) Adverse outcome pathway and risks of anticoagulant rodenticides to predatory wildlife. Environ Sci Technol 48:8433-8445. doi:10.1021/ es501740n

Rattner BA, Horak KE, Lazarus RS et al (2015) Toxicity reference values for chlorophacinone and their application for assessing anticoagulant rodenticide risk to raptors. Ecotoxicology 24:720-734. doi:10.1007/s10646-015-1418-8

Redpath SM, Clarke R, Madders M, Thirgood SJ (2001) Assessing raptor diet: comparing pellets, prey remains, and observational data at hen harrier nests. Condor 103:184-188

Reynolds M, Slotterback J, Walters J (2006) Diet composition and terrestrial prey selection of the Laysan Teal on Laysan Island. Atoll Res Bull 543:181-199

Rimmer CC, Mcfarland KP, Evers DC et al (2005) Mercury concentrations in Bicknell's thrush and other insectivorous passerines in Montane forests of northeastern North America. Ecotoxicology 14:223-240

Rüdel H, Böhmer W, Schröter-Kermani C (2006) Retrospective monitoring of synthetic musk compounds in aquatic biota from German rivers and coastal areas. J Environ Monit 8:812-823. doi: $10.1039 / \mathrm{b} 602389 \mathrm{~b}$

Ruder MG, Poppenga RH, Bryan JA 2nd et al (2011) Intoxication of nontarget wildlife with rodenticides in northwestern Kansas. J Wildl Dis 47:212-216

Rundlöf M, Andersson GKS, Bommarco R et al (2015) Seed coating with a neonicotinoid insecticide negatively affects wild bees. Nature 521:77-80. doi:10.1038/nature14420

Rutz C, Bijlsma RG, Marquiss M, Kenward RE (2006) Population limitation in the Northern Goshawk in Europe: a review with case studies. In: Morrison ML (ed) The Northern Goshawk: a technical assessment of its status, ecology and management. Cooper Ornithological Society, pp 158-197

Sánchez-Virosta P, Espín S, García-Fernández AJ, Eeva T (2015) A review on exposure and effects of arsenic in passerine birds. Sci Total Environ 512-513:506-525. doi:10.1016/j.scitotenv.2015. 01.069

Sandermann H Jr (2003) Differential lipid affinity of xenobiotics and natural compounds. FEBS Lett 554:165-168 
Sauer E, Moro AM, Brucker $N$ et al (2014) Liver $\delta$-aminolevulinate dehydratase activity is inhibited by neonicotinoids and restored by antioxidant agents. Int $\mathbf{J}$ Environ Res Public Health 11:11676-11690. doi:10.3390/ijerph111111676

Scheuhammer AM (1987) The chronic toxicity of aluminium, cadmium, mercury, and lead in birds: a review. Environ Pollut 46:263-295

Scheuhammer AM, Templeton DM (1998) Use of stable isotope ratios to distinguish sources of lead exposure in wild birds. Ecotoxicology 7:37-42. doi:10.1023/A:1008855617453

Scheuhammer AM, Basu N, Burgess NM et al (2008) Relationships among mercury, selenium, and neurochemical parameters in common loons (Gavia immer) and bald eagles (Haliaeetus leucocephalus). Ecotoxicology 17:93-101. doi:10.1007/s10646007-0170-0

Sergio F, Newton I, Marchesi L (2005) Conservation: top predators and biodiversity. Nature 436:192-192. doi:10.1038/436192a

Sharma AK, Saini M, Singh SD et al (2014) Diclofenac is toxic to the Steppe Eagle Aquila nipalensis: widening the diversity of raptors threatened by NSAID misuse in South Asia. Bird Conser Int 24:282-286. doi:10.1017/S0959270913000609

Shimshoni JA, Evgeny E, Lublin A et al (2012) Determination of brain cholinesterase activity in normal and pesticide exposed wild birds in Israel. Israel J Veterinary Med 67:214-219

Shlosberg A, Rumbeiha WK, Lublin A, Kannan K (2011a) A database of avian blood spot examinations for exposure of wild birds to environmental toxicants: the DABSE biomonitoring project. J Environ Monit 13:1547-1558. doi:10.1039/c0em00754d

Shlosberg A, Wu Q, Rumbeiha WK et al (2011b) Examination of Eurasian griffon vultures (Gyps fulvus fulvus) in Israel for exposure to environmental toxicants using dried blood spots. Arch Environ Contam Toxicol. doi:10.1007/s00244-011-9709-4

Shore RF, Osborn D, Wienburg CL et al (2005) Potential modifications to the Predatory Bird Monitoring Scheme (PBMS): second report. Joint Nature Conservation Committee, Peterborough

Shore RF, Pereira MG, Walker LA, Thompson DR (2011) Mercury in nonmarine birds and mammals. In: Beyer WN, Meador JP (eds) Environmental contaminants in biota: interpreting tissue concentrations. CRC Press, Taylor \& Francis, Boca Raton, pp 609-627

Shore RF, Taggart MA, Smits J et al (2014) Detection and drivers of exposure and effects of pharmaceuticals in higher vertebrates. Philos Trans R Soc Lond B 369:20130570. doi:10.1098/rstb.2013.0570

Shore RF, Pereira MG, Potter ED, Walker LA (2015) Monitoring rodenticide residues in wildlife. In: Budde AP, Smith RH (eds) Rodent pests and their control. CAB International, Wallingford, Oxfordshire, UK, pp 346-365

Sielicki J, Mizera T (2009) Peregrine Falcon populations - status and perspectives in the 21st century. Turul Publishing and Poznan University of Life Sciences Press, Warsaw

Sillanpää S, Salminen J-P, Eeva T (2010) Fluctuating asymmetry in great tit nestlings in relation to diet quality, calcium availability and pollution exposure. Sci Total Environ 408:3303-3309. doi:10.1016/j.scitotenv.2010.03.024

Solheim SA (2010) The preen gland-an organ for excretion of persistent organic pollutants in black-legged kittiwake (Rissa tridactyla). Master thesis, University of Bergen

Solonen T, Lodenius M, Tulisalo E (1999) Metal levels of feathers in birds of various food chains in southern Finland. Ornis Fennica 76(1):25-32

Sonne C, Bustnes JO, Herzke D et al (2010) Relationships between organohalogen contaminants and blood plasma clinical-chemical parameters in chicks of three raptor species from Northern Norway. Ecotoxicol Environ Saf 73:7-17. doi:10.1016/j.ecoenv. 2009.08.017
Spann JW, Heath RG, Kreitzer JF, Locke LN (1972) Ethyl mercury p-toluene sulfonanilide: lethal and reproductive effects on pheasants. Science 175:328-331

Speake BK, Murray AM, Noble RC (1998) Transport and transformations of yolk lipids during development of the avian embryo. Prog Lipid Res 37:1-32

Speller CF, Nicholas GP, Yang DY (2011) Feather barbs as a good source of mtDNA for bird species identification in forensic wildlife investigations. Investig Genet 2:16. doi:10.1186/2041-2223-2-16

Stahl T, Mattern D, Brunn H (2011) Toxicology of perfluorinated compounds. Environ Sci Eur 23:38. doi:10.1186/2190-4715-23-38

Stickel LF, Wiemeyer SN, Blus LJ (1973) Pesticide residues in eggs of wild birds: adjustment for loss of moisture and lipid. Bull Environ Contam Toxicol 9:193-196. doi:10.1007/BF01684824

Stove CP, Ingels A-SME, De Kesel PMM, Lambert WE (2012) Dried blood spots in toxicology: from the cradle to the grave? Crit Rev Toxicol 42:230-243. doi:10.3109/10408444.2011.650790

Strong RJ, Pereira MG, Shore RF et al (2015) Feather corticosterone content in predatory birds in relation to body condition and hepatic metal concentration. Gen Comp Endocrinol 214:47-55. doi:10.1016/j.ygcen.2015.03.002

Sun L, Xie Z (2001) Changes in lead concentration in Antarctic penguin droppings during the past 3,000 years. Environ Geol 40:1205-1208. doi:10.1007/s002540100346

Sun L, Yin X, Pan C, Wang Y (2005) A 50-years record of dichlorodiphenyl-trichloroethanes and hexachlorocyclohexanes in lake sediments and penguin droppings on King George Island, Maritime Antarctic. J Environ Sci (China) 17:899-905

Sun L, Yin X, Liu X et al (2006) Levels of hexachlorocyclohexanes and Dichloro-Dipheny-Trichloroethanes in penguin droppings collected from Ardley Island, Maritime Antarctic. Hum Ecol Risk Assess 12:328-338. doi:10.1080/10807030500536819

Swan GE, Cuthbert R, Quevedo M et al (2006) Toxicity of diclofenac to Gyps vultures. Biol Lett 2:279-282. doi:10.1098/rsbl.2005. 0425

Taggart MA, Senacha KR, Green RE et al (2009) Analysis of nine NSAIDs in ungulate tissues available to critically endangered vultures in India. Environ Sci Technol 43:4561-4566

Terraube J, Arroyo B, Madders M, Mougeot F (2011) Diet specialisation and foraging efficiency under fluctuating vole abundance: a comparison between generalist and specialist avian predators. Oikos 120:234-244. doi:10.1111/j.1600-0706.2010. 18554.X

Thomas NJ (1999) Barbiturates (Chap. 48). In: Field manual of wildlife disease-general field procedures and diseases of birds, pp 349-350. http://www.nwhc.usgs.gov/publications/field_manual/

Thomas PJ, Mineau P, Shore RF et al (2011) Second generation anticoagulant rodenticides in predatory birds: probabilistic characterisation of toxic liver concentrations and implications for predatory bird populations in Canada. Environ Int 37:914-920. doi:10.1016/j.envint.2011.03.010

Thompson DR, Furness RW (1989a) Comparison of the levels of total and organic mercury in seabird feathers. Mar Pollut Bull 20:557-579

Thompson DR, Furness RW (1989b) The chemical form of mercury stored in South Atlantic seabirds. Environ Pollut 60:305-317. doi:10.1016/0269-7491(89)90111-5

Thompson DR, Hamer KC, Furness RW (1991) Mercury accumulation in great skuas Catharacta skua of known age and sex, and its effects upon breeding and survival. J Appl Ecol 28:672. doi: $10.2307 / 2404575$

Tokumoto J, Danjo M, Kobayashi Y et al (2013) Effects of exposure to clothianidin on the reproductive system of male quails. $\mathrm{J}$ Vet Med Sci 75:755-760 
Trierweiler C, Hegemann A (2011) Food intake in a Montagu's harrier estimated by two methods of pellet analysis. J Raptor Res 45:184-188. doi:10.3356/JRR-10-34.1

Van Den Brink NW (1997) Preen gland oil and blood samples: nondestructive methods for monitoring organochlorine levels in Antartic top predators. In: Battaglia B, Valencia J, Walton DWH (eds) Antarctic communities, species structure and survival. Cambridge University Press, Cambridge, pp 413-416

Van Drooge B, Mateo R, Vives I et al (2008) Organochlorine residue levels in livers of birds of prey from Spain: inter-species comparison in relation with diet and migratory patterns. Environ Pollut 153:84-91. doi:10.1016/j.envpol.2007.07.029

van Iersel JJA, Bol ACA (1958) Preening of two tern species. A study on displacement activities. Behaviour 13:1-88

Vandenbroucke V, Bousquet-Melou A, De Backer P, Croubels S (2008) Pharmacokinetics of eight anticoagulant rodenticides in mice after single oral administration. J Vet Pharmacol Ther 31:437-445. doi:10.1111/j.1365-2885.2008.00979.x

Vetter W, von der Recke R, Herzke D, Nygård T (2008) Detailed analysis of polybrominated biphenyl congeners in bird eggs from Norway. Environ Pollut 156:1204-1210. doi:10.1016/j.envpol. 2008.04.003

Volz SA, Johnston JJ, Griffin DL (2001) Solid phase extraction gas chromatography/electron capture detector method for the determination of organochlorine pesticides in wildlife whole blood. J Agric Food Chem 49:2741-2745

Voorspoels S, Covaci A, Lepom P et al (2006) Levels and distribution of polybrominated diphenyl ethers in various tissues of birds of prey. Environ Pollut 144:218-227. doi:10.1016/j.envpol.2005. 12.027

Waits LP, Paetkau D (2005) Noninvasive genetic sampling tools for wildlife biologists: a review of applications and recommendations for accurate data collection. J Wildl Manag 69:1419-1433. doi:10.2193/0022-541X(2005)

Walker LA, Shore RF, Turk A et al (2008) The predatory bird monitoring scheme: identifying chemical risks to top predators in Britain. Ambio 37:466-471

Wayland M, Scheuhammer AM (2011) Cadmium in birds. In: Beyer WN, Meador JP (eds) Environmental contaminants in biota: interpreting tissue concentrations. CRC Press, Taylor \& Francis, Boca Raton, pp 645-669

Weech SA, Wilson LK, Langelier KM, Elliott JE (2003) Mercury residues in livers of bald eagles (Haliaeetus leucocephalus) found dead or dying in British Columbia, Canada (1987-1994). Arch Environ Contam Toxicol 45:562-569

Wienburg CL, Shore RF (2004) Factors influencing liver PCB concentrations in sparrowhawks (Accipiter nisus), kestrels (Falco tinnunculus) and herons (Ardea cinerea) in Britain. Environ Pollut 132:41-50. doi:10.1016/j.envpol.2004.03.027

Yamamuro T, Ohta H, Aoyama M, Watanabe D (2014) Simultaneous determination of neonicotinoid insecticides in human serum and urine using diatomaceous earth-assisted extraction and liquid chromatography-tandem mass spectrometry. J Chromatogr B Analyt Technol Biomed Life Sci 969:85-94. doi:10.1016/j. jchromb.2014.06.008

Yamashita R, Takada H, Murakami M et al (2007) Evaluation of noninvasive approach for monitoring PCB pollution of seabirds using preen gland oil. Environ Sci Technol 41:4901-4906

Yeter O, Aydin A (2014) Determination of acetamiprid and IM-1-2 in postmortem human blood, liver, stomach contents by HPLCDAD. J Forensic Sci 59:287-292. doi:10.1111/1556-4029.12368

Yin X, Xia L, Sun L et al (2008) Animal excrement: a potential biomonitor of heavy metal contamination in the marine environment. Sci Total Environ 399:179-185. doi:10.1016/j. scitotenv.2008.03.005

Yoo H, Guruge KS, Yamanaka N et al (2009) Depuration kinetics and tissue disposition of PFOA and PFOS in white leghorn chickens (Gallus gallus) administered by subcutaneous implantation. Ecotoxicol Environ Saf 72:26-36. doi:10.1016/j.ecoenv.2007. 09.007

Yorifuji T, Tsuda T, Takao S, Harada M (2008) Long-term exposure to methylmercury and neurologic signs in Minamata and neighboring communities. Epidemiology 19:3-9

Zorrilla I, Martinez R, Taggart MA, Richards N (2015) Suspected flunixin poisoning of a wild Eurasian Griffon Vulture from Spain. Conserv Biol 29:587-592. doi:10.1111/cobi.12417 